\title{
Compositional and structural analysis of engineered stones and inorganic particles in silicotic nodules of exposed workers
}

\author{
Antonio León-Jiménez ${ }^{1,2^{*}}$ (0), José M. Mánuel ${ }^{3,4}$, Marcial García-Rojo ${ }^{5,2}$, Marina G. Pintado-Herrera ${ }^{6,7}$, \\ José Antonio López-López ${ }^{6,8}$, Antonio Hidalgo-Molina 1,2, Rafael García 3,9, Pedro Muriel-Cueto ${ }^{5,2}$, \\ Nieves Maira-González ${ }^{10}$, Daniel Del Castillo-Otero ${ }^{11}$ and Francisco M. Morales 3,9
}

\begin{abstract}
Background: Engineered stone silicosis is an emerging disease in many countries worldwide produced by the inhalation of respirable dust of engineered stone. This silicosis has a high incidence among young workers, with a short latency period and greater aggressiveness than silicosis caused by natural materials. Although the silica content is very high and this is the key factor, it has been postulated that other constituents in engineered stones can influence the aggressiveness of the disease. Different samples of engineered stone countertops (fabricated by workers during the years prior to their diagnoses), as well as seven lung samples from exposed patients, were analyzed by multiple techniques.
\end{abstract}

Results: The different countertops were composed of $\mathrm{SiO}_{2}$ in percentages between 87.9 and $99.6 \%$, with variable relationships of quartz and cristobalite depending on the sample. The most abundant metals were $\mathrm{Al}, \mathrm{Na}, \mathrm{Fe}, \mathrm{Ca}$ and Ti. The most frequent volatile organic compounds were styrene, toluene and $\mathrm{m}$-xylene, and among the polycyclic aromatic hydrocarbons, phenanthrene and naphthalene were detected in all samples. Patients were all males, between 26 and 46 years-old (average age: 36 ) at the moment of the diagnosis. They were exposed to the engineered stone an average time of 14 years. At diagnosis, only one patient had progressive massive fibrosis. After a follow-up period of $8 \pm 3$ years, four patients presented progressive massive fibrosis. Samples obtained from lung biopsies most frequently showed well or ill-defined nodules, composed of histiocytic cells and fibroblasts without central hyalinization. All tissue samples showed high proportion of Si and Al at the center of the nodules, becoming sparser at the periphery. Al to Si content ratios turned out to be higher than 1 in two of the studied cases. Correlation between $\mathrm{Si}$ and Al was very high $(r=0.93)$.

Conclusion: Some of the volatile organic compounds, polycyclic aromatic hydrocarbons and metals detected in the studied countertop samples have been described as causative of lung inflammation and respiratory disease. Among inorganic constituents, aluminum has been a relevant component within the silicotic nodule, reaching atomic concentrations even higher than silicon in some cases. Such concentrations, both for silicon and aluminum showed a decreasing tendency from the center of the nodule towards its frontier.

*Correspondence: antonio.leon.sspa@juntadeandalucia.es

1 Pulmonology, Allergy and Thoracic Surgery Department, Puerta del Mar University Hospital, Cádiz, Spain

Full list of author information is available at the end of the article permits use, sharing, adaptation, distribution and reproduction in any medium or format, as long as you give appropriate credit to the original author(s) and the source, provide a link to the Creative Commons licence, and indicate if changes were made. The images or other third party material in this article are included in the article's Creative Commons licence, unless indicated otherwise in a credit line to the material. If material is not included in the article's Creative Commons licence and your intended use is not permitted by statutory regulation or exceeds the permitted use, you will need to obtain permission directly from the copyright holder. To view a copy of this licence, visit http://creativecommons.org/licenses/by/4.0/. The Creative Commons Public Domain Dedication waiver (http://creativeco mmons.org/publicdomain/zero/1.0/) applies to the data made available in this article, unless otherwise stated in a credit line to the data. 
Keywords: Artificial stone, Engineered stone, Quartz agglomerate, Silicosis, Silica, Aluminum, Volatile organic compounds

\section{Introduction}

Silicosis is an occupational respiratory disease produced by the inhalation of respirable crystalline silica; after disease onset, pulmonary fibrosis occurs, which can lead to respiratory failure and death [1]. It is a disease which incidence has been progressively reduced in recent years in countries with higher gross domestic product [2] due to the adoption of prevention measures and epidemiological surveillance, in addition to the displacement of mining activity to other countries with lower production costs. In the 1990s, the commercialization of a compound artificial material called quartz agglomerate, artificial stone or engineered stone (ES) began. This material is manufactured with finely crushed rock, with a silica content generally greater than $90 \%$, together with pigments and polymeric resins [3] acting as binders of the inorganic portion. The design of this material and its attractive colors has made its use widespread in some countries as kitchen or bathroom countertops. Starting in 2009, cases of silicosis began to be described in workers who fabricate and install ES countertops, even producing two outbreaks focused in Israel [4] and Spain [5] and cases in countries such as Italy [6], the United States [7] and Australia [8], among others. In Australia, the significant number of cases detected has led to the consideration of ES related silicosis as an occupational epidemic [9]. One of the characteristics of ES silicosis is its short latency period and its aggressiveness [10], evolving to progressive massive fibrosis (PMF) in up to $37.7 \%$ of patients in a short period of time, even after having abandoned exposure to silica [11]. Several factors have been postulated as participants in the aggressiveness of this disease. One of them is the high silica content of which this material is composed, and another possibility is that the different components of ES, such transition metals or other elements, intensify the pulmonary fibrogenic response produced by silica $[3,6]$.

In 2009, an outbreak of ES silicosis began in our geographic area (the Bay of Cadiz, at the South of Spain), with a significant number of cases detected in subsequent years [5]. The objective of our study is to determine the different constituents that make up kitchen and bathroom countertops and to establish the localization of the deposit of metals and their atomic concentrations in lung tissue of ES workers diagnosed with silicosis. To address those goals, we have analyzed: (i) seven samples of those countertops with which patients more frequently worked during the years previous to their diagnosis; and (ii) lung biopsies samples, from the Anatomic Pathology files, of seven of those patients exposed to dusts of particles of these materials.

\section{Results \\ ES samples}

The first phase of the study consisted of analyzing the composition and structure of the composite materials with which the patients had worked during the years of exposure to ES. Samples were supplied by the Spanish National Association of Silicosis-Affected and -Sick People, having been selected among those most frequently utilized in the Bay of Cadiz region. The X-ray diffraction (XRD), X-ray fluorescence (XRF) and inductively coupled plasma mass spectrometry (ICP-MS) results for samples M1-M7 are included in Table 1.

Regarding the different polymorphic phases of crystalline silica $\left(\mathrm{SiO}_{2}\right)$ detected by XRD, samples M6 and M7 are formed exclusively of quartz, and samples M1 and M3 are almost fully, or completely, based on cristobalite, respectively. The rest of samples showed variable mixtures of cristobalite and quartz, with a remarkable portion assignable to albite $\left(\mathrm{NaAlSi}_{3} \mathrm{O}_{8}\right)$ in one of the samples (M2). Considering the mostly present elements in the XRF studies (only those over 0.1 at.\% are considered), $\mathrm{O}$ and $\mathrm{Si}$ were measured in percentages that agree well with the 2:1 ratio corresponding to $\mathrm{SiO}_{2}$. The XRD observed presence of albite in M2 is also in agreement with the XRF results (for a slightly Ca-doped albite). Since XR fluorescence (microanalysis) focus in a much smaller region of the sample than XR diffraction (more macroscopic analysis), probably a similar tectosilicate of the feldspar mineral group consisting in a solid solution of albite and anorthite endmembers $\left(\mathrm{NaAlSi}_{3} \mathrm{O}_{8}-\mathrm{CaAl}\right.$ ${ }_{2} \mathrm{Si}_{2} \mathrm{O}$ ) was probed in the portion of the sample M7 tested by XRF, considering the elemental quantifications.

Note that additional metallic elements were detected in smaller concentrations by XRF for which their quantifications would not be trustable, so focused analyses to these trace species were performed by ICP-MS (As, Cd, $\mathrm{Co}, \mathrm{Cu}, \mathrm{Ni}, \mathrm{Pb}, \mathrm{Zn}, \mathrm{Ba}, \mathrm{Mo}, \mathrm{Sb}, \mathrm{V}$ ) or ICP-AES (Al, Fe, $\mathrm{Ca}, \mathrm{Na}, \mathrm{Ti}, \mathrm{W})$, as well as for other metals that are known to be harmful. The concentrations of these metals were variable between the different types of ES samples. The most abundant elements were $\mathrm{Al}, \mathrm{Na}, \mathrm{Fe}, \mathrm{Ca}, \mathrm{Ti}$ and $\mathrm{W}$, some of which showed concentrations above $1 \mathrm{~g} / \mathrm{kg}$ in some of the samples. Elements such as $\mathrm{Co}, \mathrm{Cu}, \mathrm{Ni}, \mathrm{Zn}$ and $\mathrm{Ba}$ were present in variable concentrations between 
Table 1 Percentages of crystalline phases measured by XRD, atomic percentage of more often elements measured by XRF, and trace elemental analyses of specific metal species by ICP-MS

\begin{tabular}{|c|c|c|c|c|c|c|c|}
\hline Sample/method & M1 & M2 & M3 & M4 & M5 & M6 & M7 \\
\hline $\begin{array}{l}\text { XRD } \\
\text { (cryst. \%) }\end{array}$ & $\begin{array}{l}2 \% \text { Qu } \\
98 \% \text { Cri }\end{array}$ & $\begin{array}{l}25 \% \text { Qu } \\
45 \% \text { Cri } \\
30 \% \text { Alb }\end{array}$ & $100 \%$ Cri & $\begin{array}{l}53 \% \text { Qu } \\
47 \% \text { Cri }\end{array}$ & $\begin{array}{l}56 \% \text { Qu } \\
44 \% \text { Cri }\end{array}$ & $100 \%$ Qu & $100 \%$ Qu \\
\hline $\begin{array}{l}\text { XRF } \\
\text { at. \%* }\end{array}$ & $\begin{array}{l}66.6 \mathrm{O} \\
32.7 \mathrm{Si} \\
0.5 \mathrm{Ti}\end{array}$ & $\begin{array}{l}64.5 \mathrm{O} \\
29.3 \mathrm{Si} \\
3.3 \mathrm{Na} \\
2.5 \mathrm{Al} \\
0.2 \mathrm{Ti} \\
0.1 \mathrm{Ca}\end{array}$ & $\begin{array}{l}66.7 \mathrm{O} \\
32.7 \mathrm{Si} \\
0.6 \mathrm{Ti}\end{array}$ & $\begin{array}{l}66.6 \mathrm{O} \\
33.2 \mathrm{Si} \\
0.1 \mathrm{Ti}\end{array}$ & $\begin{array}{l}66.7 \mathrm{O} \\
33.2 \mathrm{Si}\end{array}$ & $\begin{array}{l}66.6 \mathrm{O} \\
32.9 \mathrm{Si} \\
0.3 \mathrm{Ti}\end{array}$ & $\begin{array}{l}64.4 \mathrm{O} \\
30.4 \mathrm{Si} \\
3.3 \mathrm{Na} \\
1.4 \mathrm{Ca} \\
0.1 \mathrm{Mg}\end{array}$ \\
\hline \multicolumn{8}{|l|}{$\operatorname{ICP}(\mathrm{mg} / \mathrm{kg})^{* *}$} \\
\hline As & $<0.2$ & $<0.2$ & $<0.2$ & $<0.2$ & $<0.2$ & $<0.2$ & $<0.2$ \\
\hline $\mathrm{Cd}$ & 0.014 & 0.007 & 0.006 & $<0.003$ & $<0.003$ & 0.006 & 0.015 \\
\hline Co & 42.2 & 62.4 & 29 & 127 & 102 & 75 & 71.3 \\
\hline $\mathrm{Cu}$ & 4.93 & 13 & 5.30 & 98.1 & 50.2 & 58 & 96.0 \\
\hline $\mathrm{Ni}$ & 5.21 & 9.1 & 3.21 & 21.6 & 16.4 & 12 & 12.4 \\
\hline $\mathrm{Pb}$ & 1.1 & 1.95 & 1.2 & 0.53 & 0.66 & 2.21 & 409 \\
\hline $\mathrm{Zn}$ & 3 & 20.5 & 6.56 & 256 & 59.5 & 228 & 312 \\
\hline $\mathrm{Ba}$ & 24 & 16 & 25 & 11 & 10.3 & 13.4 & 262 \\
\hline Mo & 0.222 & 0.251 & 0.204 & 0.385 & 7.44 & 0.280 & 0.413 \\
\hline $\mathrm{Sb}$ & 0.151 & 0.150 & 0.154 & 0.150 & 0.170 & 0.154 & 0.413 \\
\hline V & 0.971 & 1.72 & 0.870 & 0.592 & 208 & 0.830 & 2.20 \\
\hline $\mathrm{Ti}$ & 8992 & 2861 & 9527 & 1067 & 691 & 4228 & 614 \\
\hline $\mathrm{Al}$ & 1730 & 43,000 & 1622 & 1439 & 1900 & 1755 & 536 \\
\hline $\mathrm{Ca}$ & 124 & 3188 & 115 & 152 & 169 & 143 & 45,546 \\
\hline $\mathrm{Na}$ & 1913 & 30,250 & 2054 & 1216 & 1437 & 351 & 38,281 \\
\hline $\mathrm{Fe}$ & 250 & 334 & 235 & 506 & 400 & 523 & 670 \\
\hline W & 281 & 564 & 156 & 1221 & 1015 & 695 & 705 \\
\hline
\end{tabular}

${ }^{*}$ Measurements $<0.1 \%$ have been discarded

${ }^{*}$ Limits of detection $(\mathrm{mg} / \mathrm{kg}): \mathrm{As}=0.2, \mathrm{Cd}=0.003, \mathrm{Co}=0.230 \mathrm{Cu}=0.120, \mathrm{Ni}=0.084, \mathrm{~Pb}=0.240, \mathrm{Zn}=0.580, \mathrm{Ba}=0.360, \mathrm{Mo}=0.130, \mathrm{Sb}=0.060, \mathrm{~V}=0.130, \mathrm{Al}=100$, $\mathrm{Fe}=10, \mathrm{Ca}=20, \mathrm{Na}=110, \mathrm{Ti}=4, \mathrm{~W}=30$

Qu quartz, Cri cristobalite, Alb albite, XRD X-ray diffraction, XRF X-ray fluorescence, ICP Inductively coupled plasma

3 and $312 \mathrm{mg} / \mathrm{kg}$. The metals considered more toxic, such as $\mathrm{As}, \mathrm{Cd}$, or $\mathrm{Pb}$, were detected at concentrations below $0.2 \mathrm{mg} / \mathrm{kg}$, except $\mathrm{Pb}$, that ranged from 0.53 to $409 \mathrm{mg} /$ $\mathrm{kg}$. Other elements, such as Mo, Sb and V, were also present but in lower concentrations.

Based on the gas chromatography coupled to-mass spectrometry (GC-MS) results (Table 2), the M5 sample had the highest concentration of volatile and semivolatile organic compounds (VOCs), i.e., $3.21 \mathrm{mg} / \mathrm{kg}$ for the volatiles considered. The common compound in all samples was styrene, while $\mathrm{m}$-xylene and toluene were found in 4 of the samples. Notably, organic compounds not included in the analysis (non-target, $\mathrm{Nt}$ ) were identified in all samples, with sample M5 showing the highest number (5 $\mathrm{Nt}$ in total). With respect to polychlorinated biphenyls (PCBs) and polycyclic aromatic hydrocarbons (PAHs), PCBs were not detected in any of the samples analyzed, and among the PAHs, phenanthrene, naphthalene, fluorene and fluoranthene stood out in the different samples. The sample that showed the highest concentration of PAHs was M7, with a value of $95.8 \mathrm{ng} / \mathrm{g}$, and M2 showed the greatest number of different compounds ( 9 in total), some of which were below the limit of quantification or at the limit of detection.

\section{Patients and biopsy samples}

Patients were all male and they had been working cutting and polishing slabs of ES in small factories and in-home installation of ES countertops. Their ages ranged from 26 to 46 years (mean \pm SD: $35.8 \pm 6.5$ ) and the exposure took place during periods of time from 10 to 23 years (mean \pm SD: $13.7 \pm 4.6$ ), as presented in Table 3 .

Samples of the lung were obtained using transbronchial biopsy (BTB) for five of the patients, and via videoassisted thoracoscopic surgery (VATS), in the case of the other two patients. Afterwards, the so-obtained biopsies were conserved in paraffin blocks, that allowed further processing. 
Table 2 Concentrations of organic compounds (analyzed by GC-MS*)

\begin{tabular}{|c|c|c|c|c|c|c|c|}
\hline Sample & M1 & M2 & M3 & M4 & M5 & M6 & M7 \\
\hline $\operatorname{VOCs}{ }^{\dagger}(\mathrm{mg} / \mathrm{kg})$ & $\begin{array}{l}\text { STY: } 0.81 \\
\text { BAL: Nt } \\
\text { PA: Nt } \\
\text { BA: Nt }\end{array}$ & $\begin{array}{l}\text { STY: } 0.79 \\
\text { BAL: Nt } \\
\text { PA: Nt } \\
\text { TCS: Nt }\end{array}$ & $\begin{array}{l}\text { STY: } 0.76 \\
\text { 2EH: } 0.87 \\
\text { PA2DM: Nt } \\
\text { BAL: Nt } \\
\text { PA: Nt } \\
\text { TCS: Nt }\end{array}$ & $\begin{array}{l}\text { STY: } 0.83 \\
\text { mX: } 0.71 \\
\text { TOL: } 0.75 \\
\text { 2EH: } 0.9 \\
\text { TMA: Nt } \\
\text { BAL: Nt } \\
\text { PA: Nt } \\
\text { TCS: Nt }\end{array}$ & $\begin{array}{l}\text { STY: } 0.81 \\
\text { mX: } 0.73 \\
\text { TOL: } 0.79 \\
\text { 2EH: } 0.88 \\
\text { BAL: Nt } \\
\text { PA: Nt } \\
\text { PA2DM: Nt } \\
\text { DPG: Nt } \\
\text { TCS: Nt }\end{array}$ & $\begin{array}{l}\text { STY: } 0.74 \\
\text { mX: } 0.85 \\
\text { TOL: } 0.80 \\
\text { BAL: Nt } \\
\text { PA: Nt }\end{array}$ & $\begin{array}{l}\text { STY: } 0.88 \\
\text { mX: } 0.71 \\
\text { TOL: } 0.71 \\
\text { BAL: Nt } \\
\text { PA: Nt } \\
\text { BA: Nt }\end{array}$ \\
\hline $\mathrm{PAHs}^{\ddagger}(\mathrm{ng} / \mathrm{g})$ & $\begin{array}{l}\text { ACY: LOD } \\
\text { ANT: ND } \\
\text { BaA: ND } \\
\text { CH: LOQ } \\
\text { FLA: } 9.2 \\
\text { FLU: } 18.0 \\
\text { NAP: } 10.8 \\
\text { PHE: } 17.7 \\
\text { PYR: ND }\end{array}$ & $\begin{array}{l}\text { ACY: LOD } \\
\text { ANT: } 18.5 \\
\text { BaA: LOQ } \\
\text { CHR: LOQ } \\
\text { FLA: } 9.4 \\
\text { FLU: } 18.8 \\
\text { NAP: } 22.9 \\
\text { PHE: } 20.8 \\
\text { PYR: LOQ }\end{array}$ & $\begin{array}{l}\text { ACY: LOD } \\
\text { ANT: LOD } \\
\text { BaA: ND } \\
\text { CHR: LOD } \\
\text { FLA: ND } \\
\text { FLU: } 17.0 \\
\text { NAP: } 14.4 \\
\text { PHE: } 17.8 \\
\text { PYR: LOQ }\end{array}$ & $\begin{array}{l}\text { ACY: LOD } \\
\text { ANT: LOD } \\
\text { BaA: ND } \\
\text { CHR: LOQ } \\
\text { FLA: ND } \\
\text { FLU: } 17.1 \\
\text { NAP: } 15.3 \\
\text { PHE: } 18.2 \\
\text { PYR: ND }\end{array}$ & $\begin{array}{l}\text { ACY: LOD } \\
\text { ANT: ND } \\
\text { BaA: ND } \\
\text { CHR: LOD } \\
\text { FLA: ND } \\
\text { FLU: ND } \\
\text { NAP: } 14.7 \\
\text { PHE: } 19.1 \\
\text { PYR: LOQ }\end{array}$ & $\begin{array}{l}\text { ACY: LOQ } \\
\text { ANT: ND } \\
\text { BaA: ND } \\
\text { CHR: LOQ } \\
\text { FLA: ND } \\
\text { FLU: } 16.5 \\
\text { NAP: } 9.3 \\
\text { PHE: } 21.6 \\
\text { PYR: ND }\end{array}$ & $\begin{array}{l}\text { ACY: LOQ } \\
\text { ANT: ND } \\
\text { BaA: ND } \\
\text { CHR: LOQ } \\
\text { FLA: } 9.5 \\
\text { FLU: } 18.3 \\
\text { NAP: } 39.3 \\
\text { PHE: } 28.8 \\
\text { PYR: LOQ }\end{array}$ \\
\hline
\end{tabular}

* GC-MS: Gas chromatography-mass spectrometry

+ VOCs: Volatile organic compounds

₹ PAHs: Polycyclic aromatic hydrocarbons

2EH 2-ethyl-1-hexanol, $B A L$ benzaldehyde, $B A$ benzyl alcohol, $P A 2 D M$ propanoic acid2,2 dimethyl, $m X \mathrm{~m}$-xylene, $P A$ phthalic acid, $T M A$ trimethylacetic acid, STY styrene, $T O L$ toluene, DPG dipropylene glycol, TCS triclosan, $A C Y$ acenaphthylene, ANT anthracene, BaA benzanthracene, CHR chrysene, FLA fluoranthene, FLU fluorine, NAP naphthalene, PHE phenanthrene, $P Y R$ pyrene, Nt (nontarget) compounds detected (NIST Database) but not quantified, ND not detected, LOD limit of detection, $L O Q$ limit of quantification

Table 3 Sociodemographic and epidemiological data

\begin{tabular}{|c|c|c|c|c|c|c|c|}
\hline Patients & Age $^{*}$ & Year* & $\begin{array}{l}\text { Duration of exposure } \\
\text { (years) }\end{array}$ & Latency $^{\dagger}$ & $\underset{\ddagger}{\text { Smoking status* }}$ & pack-years* & $\begin{array}{l}\text { Type } \\
\text { of lung } \\
\text { biopsy }\end{array}$ \\
\hline $\mathrm{S} 1$ & 26 & 2010 & 10 & 10 & $S$ & 10 & TBB \\
\hline $\mathrm{S} 2$ & 31 & 2010 & 15 & 16 & NS & - & $\mathrm{TBB}$ \\
\hline S3 & 33 & 2010 & 10 & 11 & S & 1 & $\mathrm{TBB}$ \\
\hline S4 & 37 & 2010 & 10 & 10 & NS & - & TBB \\
\hline S5 & 37 & 2010 & 13 & 13 & S & 3 & $\mathrm{TBB}$ \\
\hline S6 & 41 & 2018 & 15 & 18 & NS & - & VATS \\
\hline S7 & 46 & 2016 & 23 & 23 & Ex & 25 & VATS \\
\hline
\end{tabular}

* At the time of lung biopsy

${ }^{\dagger}$ Latency period (years) from onset of exposure to biopsy

₹ S: Smoker. NS: Non-Smoker. Ex: Ex-smoker

$\xi$ TBB: Transbronchial biopsy. VATS: Video-assisted thoracoscopic surgery

Through tomographic cuts, histological samples (identified with the same label of the corresponding patient, as indicated in Table 3) were achieved, revealing the following patterns via light microscopy: well-defined silicotic nodule with a paucicellular lamellar fibrohyaline center and surrounded by a macrophagic population (S7), welldefined densely collagenized nodules alternating with other nodules consisting of fibroblasts and histiocytes without hyalinization (S6), well or ill-defined nodules composed of histiocytic cells and fibroblasts with some infiltration of the pulmonary interstitium by histiocytes and fibroblasts (S2-S5) or patchy interstitial infiltration consisting of fibroblasts and histiocytes reaching the alveolar septa and thickening them (S1). No one of these nodules (S1-S5) showed hyalinization.

Samples were then prepared for a nanoscale examination via scanning electron microscopy (SEM) related techniques. To this end, the biopsy samples were first prepared so the biological tissue could be studied under the electron beam. In this work, four main areas (regarding 
the silicotic nodules) for each biopsy samples were analyzed using SEM: one region in the center of the nodule, an area separated of such center, a third region close to the border of the nodule, and a fourth region practically outside of the nodule. These regions of study are referred with the labels "A", "B", "C" and "D", respectively, throughout this work. Figure 1 shows a photograph (Fig. 1a) of one of the samples, S7, indicating the place closer to the optical micrograph (Fig. 1b) obtained for the studied nodule. Over this image, a red square indicates the area around the nodule from which a low-magnification SEM image is recorded (Fig. 1c), indicating in such image those four areas (A to D) that have been detailed studied. It is worth indicating that, while samples S6 and S7 sizes were in the range of 0.5 to $1 \mathrm{~cm}$ (as can be observed in Fig. 1a), samples S1 to S5 sizes were not larger than $2 \mathrm{~mm}$, which made the micromanipulation of these samples a difficult process.

Such regions A to D were systematically studied for each sample, using SEM images of the same area (8.65 $\mu \mathrm{m}^{2}$, that is, a $\times 1000$ magnification image). Figure 2 presents representative results on this SEM study, which led to the data collected in Table 4.

Since SEM secondary electron images offer no compositional contrast, it may be difficult to even distinguish a silicotic nodule from healthy tissue using this type of signal. Therefore, as a first step, optical micrographs were utilized as guidance, in order to realize the
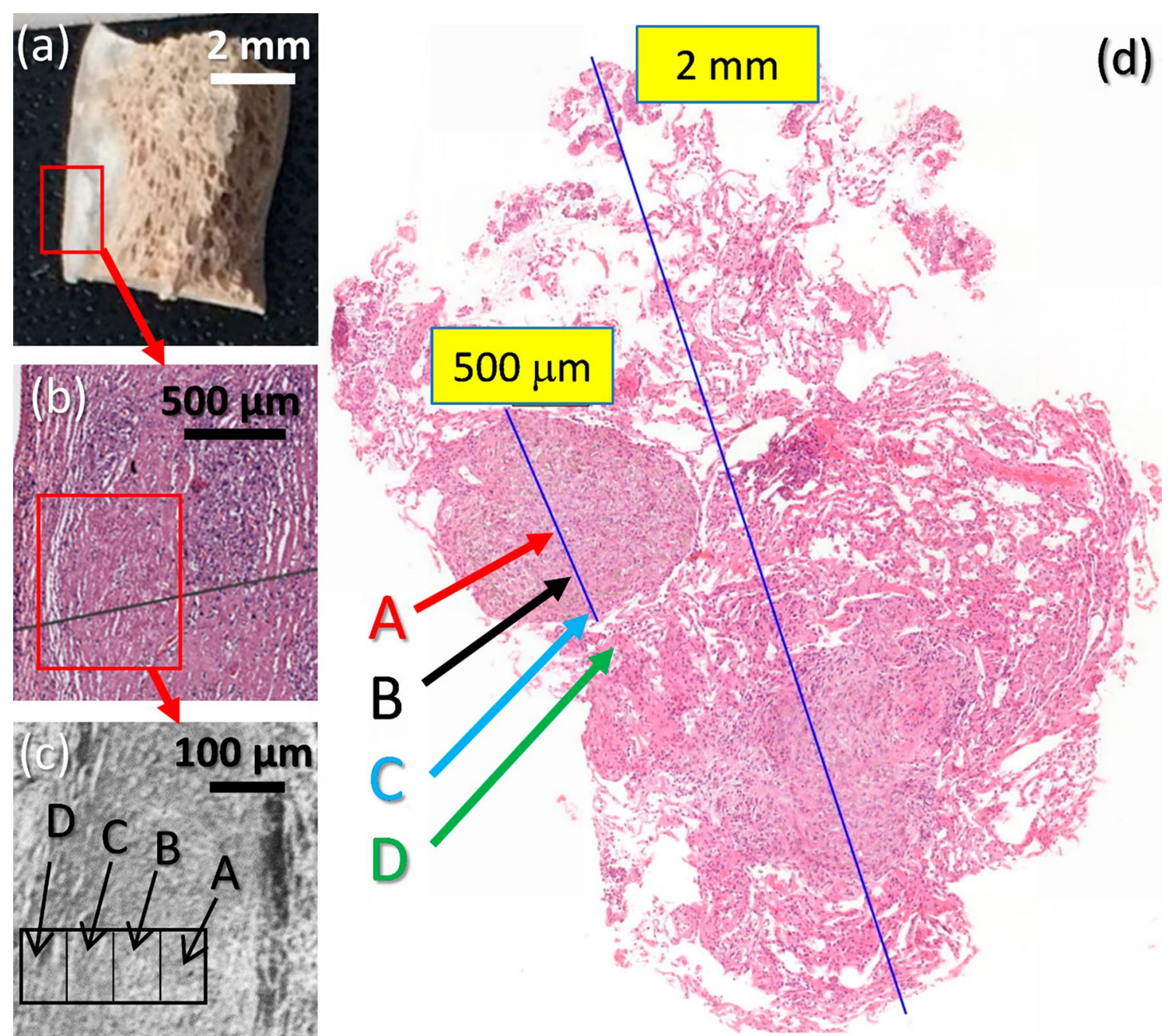

Fig. 1 Photographic image (a) and optical (b) and SEM (c) micrographs of sample S7, indicating an area surrounding a silicotic nodule close to the visceral pleura. In the SEM image, regions A to D are indicated. Histological overview of sample S3 showing the optical micrograph of a biopsy containing a well-defined nodule composed of histiocytic cells and fibroblasts, with indication of positions defined from A to D in the present study (d) 


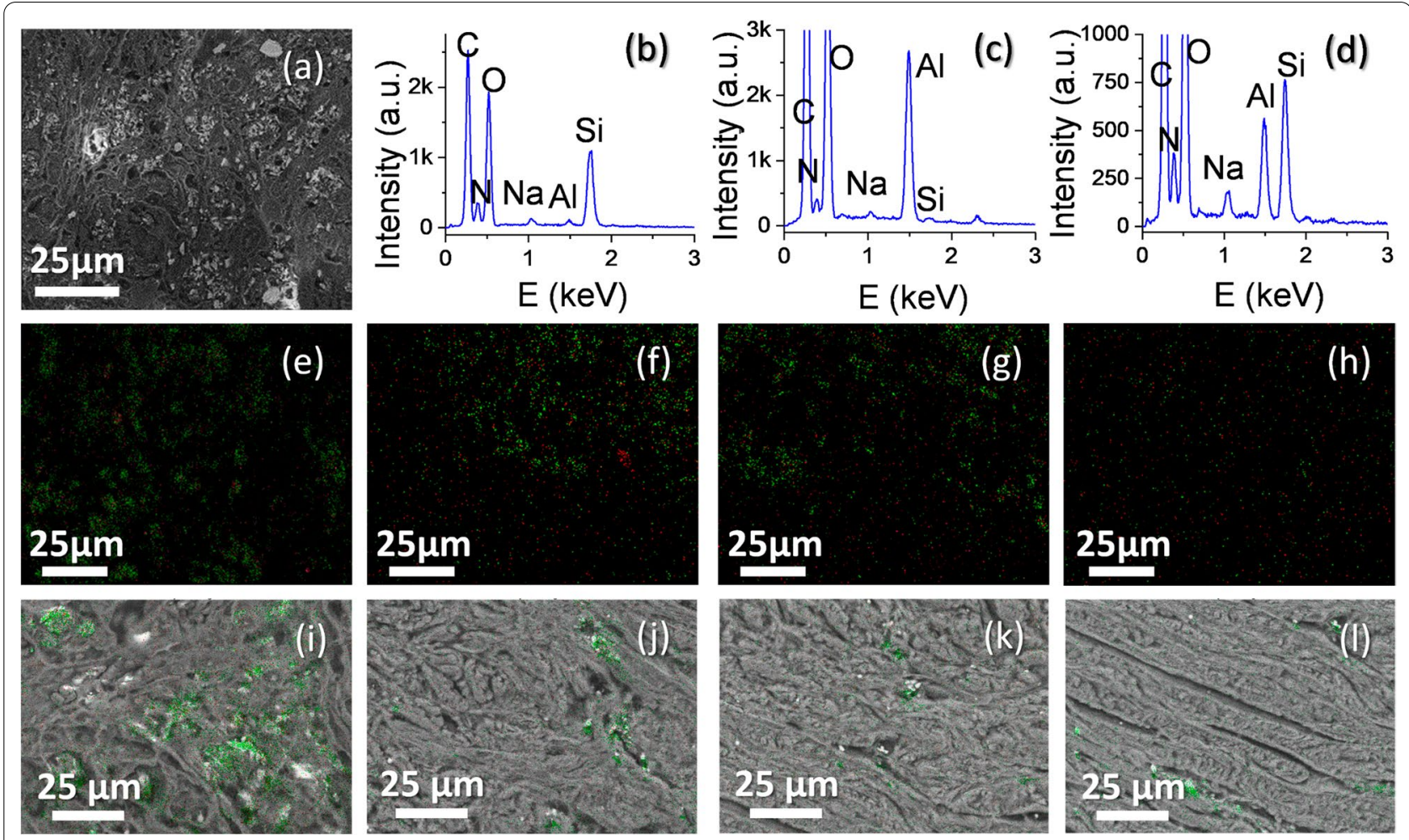

Fig. 2 BSE-SEM micrograph ( $\times 1000$ magnification) from the center of a nodule in sample S3 (a), together with representative EDX map from regions $\mathrm{A}(\mathbf{e}), \mathrm{B}(\mathbf{f}), \mathrm{C}(\mathbf{g})$ and D (h) for Si (green) and Al (red) signals. Overlay of BSE-SEM images and EDX maps for Si (green) in sample S7 for regions $A(\mathbf{i}), B(\mathbf{j}), C(\mathbf{k})$ and $D(\mathbf{l})$

approximate region where these nodules were. Next, at a higher magnification, SEM images formed by backscattered electrons (BSE) were utilized to locate the center of the nodules. This is an effective methodology since BSE images are composition sensitive, and thus, can be used as a way to reveal metal-containing particles (such as the ones consisting in different minerals formed by silicon or aluminum). Figure 2a shows a BSE image of the center of a nodule in sample S3, where the image contrast reveals a large number of micrometric particles of different composition to the organic background. These types of images show a high density of exogenous particles, presumably consisting in different minerals from the inhaled dust. Nevertheless, these images do not give more precise information on the composition of those particles, and, even, the bright regions in such images could be due to electrical charge accumulation at non-conducting areas. Thus, a spectroscopic technique had to be applied. In this sense, the energy dispersive X-ray spectroscopy (EDX) detector of the SEM was utilized in order to obtain point spectra from different particles (such as the ones presented in Fig. 2b to d), as well as map spectra from whole areas (Figs. 2e to l). When point spectra from individual particles are recorded, most particles in nodules revealed a signal similar to the one presented in Fig. 2b, where a clear Si-peak indicates (most probably) that the particle is formed by silica. In few cases, corresponding mostly to the central areas of nodules, spectra like the ones in Fig. 2c were detected. These spectra, with an Al-peak not accompanied by a Si-peak, might be associated to alumina particles, most probably. Figure $2 \mathrm{~d}$, on the other hand, reveals a more frequent spectrum than the ones presented in Fig. 2c, but not so frequent than the spectrum in Fig. 2b. This case presents both $\mathrm{Si}$ and $\mathrm{Al}$ peaks, and thus can be associated to different minerals containing both elements. It is worth mentioning that, although particle spectra such as the ones in Fig. $2 \mathrm{~b}$ are detected in all regions around the nodule (regions $A$ to $D$ ), signals of $\mathrm{Al}$ (Fig. 2c, d) are only detected on regions closer to the center of the nodule (regions $\mathrm{A}$ and $\mathrm{B}$ ).

Beside the study of particle distribution and composition, the composition of whole regions A to D for each sample were obtained, using EDX maps of all areas. Figure $2 \mathrm{e}-\mathrm{h}$ presents a representative result of EDX maps for $\mathrm{Si}$ (green) and $\mathrm{Al}$ (red) signals for regions A, B, C and $D$, respectively, in sample $S 3$. It can be observed that the center of the nodule is highly populated by Si-containing particles, and such particle density decreases for regions 
Table 4 EDX measured for atomic contents of $\mathrm{Si}$, Al and others $(\mathrm{C}, \mathrm{O}, \mathrm{N}, \mathrm{Na}, \mathrm{P}, \mathrm{S})$ for regions $\mathrm{A}$ to $\mathrm{D}$ from all biopsy samples

\begin{tabular}{|c|c|c|c|c|}
\hline Sample & Region & $\mathrm{Si}(\%)$ & Al (\%) & Others (\%) \\
\hline \multirow[t]{4}{*}{ S1 } & A & 0.11 & 0.14 & 99.75 \\
\hline & B & 0.08 & 0.03 & 99.91 \\
\hline & $C$ & 0.06 & 0.03 & 99.89 \\
\hline & $\mathrm{D}$ & 0.03 & 0.01 & 99.96 \\
\hline \multirow[t]{4}{*}{ S2 } & A & 1.81 & 0.44 & 97.75 \\
\hline & B & 0.44 & 0.14 & 9.42 \\
\hline & $C$ & 0.11 & 0.04 & 99.85 \\
\hline & $D$ & 0.02 & 0.04 & 99.94 \\
\hline \multirow[t]{4}{*}{ S3 } & $A$ & 2.09 & 0.68 & 97.23 \\
\hline & B & 1.32 & 0.24 & 98.44 \\
\hline & $C$ & 1.04 & 0.24 & 98.72 \\
\hline & $D$ & 0.08 & 0.07 & 99.85 \\
\hline \multirow[t]{4}{*}{ S4 } & A & 2.91 & 0.79 & 96.3 \\
\hline & B & 0.83 & 0.18 & 98.99 \\
\hline & $C$ & 0.55 & 0.16 & 99.29 \\
\hline & $\mathrm{D}$ & 0.12 & 0.10 & 99.78 \\
\hline \multirow[t]{4}{*}{ S5 } & $A$ & 0.08 & 0.12 & 99.80 \\
\hline & $B$ & 0.05 & 0.11 & 99.84 \\
\hline & $C$ & 0.05 & 0.10 & 99.85 \\
\hline & $D$ & 0.02 & 0.02 & 99.96 \\
\hline \multirow[t]{4}{*}{ S6 } & $A$ & 0.18 & 0.14 & 99.68 \\
\hline & $B$ & 0.08 & 0.43 & 99.49 \\
\hline & $C$ & 0.08 & 0.12 & 99.80 \\
\hline & $\mathrm{D}$ & 0.00 & 0.00 & 100.00 \\
\hline \multirow[t]{4}{*}{ S7 } & $A$ & 0.96 & 0.10 & 98.94 \\
\hline & $B$ & 0.08 & 0.09 & 99.83 \\
\hline & $C$ & 0.03 & 0.07 & 99.90 \\
\hline & $\mathrm{D}$ & 0.04 & 0.01 & 99.95 \\
\hline
\end{tabular}

further to this center. Particles with $\mathrm{Al}$ content (with or without $\mathrm{Si}$ ) were mostly found at regions $\mathrm{A}$ and $\mathrm{B}$. We found out that all the samples (S1 to S7) showed a similar trend (decreasing $\mathrm{Si}$ from regions $\mathrm{A}$ to $\mathrm{D}$; $\mathrm{Al}$ mostly presented in regions $A$ and $B$, only differing in the density of $\mathrm{Si}$ or $\mathrm{Al}$ containing particles, as will be more clearly seen from data in Table 4.

These EDX maps can be overlaid to BSE images, in such a way that it is possible to distinguish which of the bright regions in the BSE images correspond to $\mathrm{Si}(\mathrm{Al})$ containing particles from those bright regions produced by charge effects in the SEM image. An example of this is presented in Fig. 2i to h, which correspond to areas A to D, respectively, for sample S7.

In order to quantify the content of $\mathrm{Si}$ and $\mathrm{Al}$ along the nodules, for every sample, EDX spectra were taken from each region (A to D). These integrated spectra (of which examples are presented in Fig. 3, for 3 samples and regions $\mathrm{A}, \mathrm{B}$ and $\mathrm{D}$, having normalized the spectra to the N-peak consisted, in each case, in collecting the $\mathrm{X}$ ray signal coming out of each the volumes formed by the $8.65 \mu \mathrm{m}^{2}$ area and the length the electron beam extracted the $\mathrm{X}$ ray signal (about $1 \mu \mathrm{m}$, although the exact depth depends also on the material interacting with the electron beam). Thus, most of the amount of elements detected in these integrated spectra consisted in $\mathrm{C}, \mathrm{O}$ and $\mathrm{N}$, as main constituents of organic materials. Other elements found in the spectra $(\mathrm{Na}, \mathrm{P}$ and $\mathrm{S}$ ) were also components of the lung tissue. This fact lowers the percentage of $\mathrm{Si}$ and $\mathrm{Al}$ detected at each one of the regions. In this sense, Fig. 3a shows that when all peaks are fully visible, it is difficult to distinguish $\mathrm{Al}$ and $\mathrm{Si}$ peaks. Therefore, Fig. $3 \mathrm{~b}-\mathrm{d}$ presents a zoomed vertical ranged of these spectra, allowing a clear visualization of the already commented trend for $\mathrm{Al}$ and $\mathrm{Si}$ : a higher content at center of the nodule, and lower by the border. Note that two unidentified peaks appear for regions B and D in Fig. 3b, at about $0.69 \mathrm{keV}$. These artefacts, called "sum peaks", are produced when $\mathrm{C}$ and $\mathrm{N}$ characteristic X-rays reach the spectrometer spaced by times that are shorter than the detector dead time, and thus, the signals are identified as corresponding to an energy which is sum of those of the $\mathrm{C}$ and the $\mathrm{N}$. Therefore, those peaks, which are not associated to other elements, are to be disregarded.

The quantification of the elements in each sample and region was obtained from those spectra, and is collected in Table 4. In this table, the commented trend is stablished: The Si percentage was higher at the central zone of each nodule and lower towards the frontier of the nodule, while the same occurred with aluminum, which was found mainly around the central region, becoming sparser in the periphery. In all samples but one (S6), Si and $\mathrm{Al}$ were detected outside the nodule, in region $\mathrm{D}$, although in minor atomic concentrations.

There are statistically significant differences in the distribution of $\mathrm{Al}$ and $\mathrm{Si}$ atomic contents among all the areas of the nodules (A to $\mathrm{D}, p<0.05$ ). All post-hoc comparisons in these cases are significant, so these differences were present when comparing one location with any other. It is noteworthy the difference in A compared to the rest of the areas, where the atomic contents of Si and $\mathrm{Al}$ are much higher.

In a parallel preparation (not shown here) of a lung sample from a control patient, who was not professionally exposed to silica, no silicon or aluminum was detected, and only the most abundant components of the human body were found (sodium, phosphorus, sulfur, oxygen, nitrogen and carbon).

Radiological classification and progression are shown in Table 5. Five patients have been followed up during ten years, and they have shown radiological progression, and four are currently classified as PMF. 

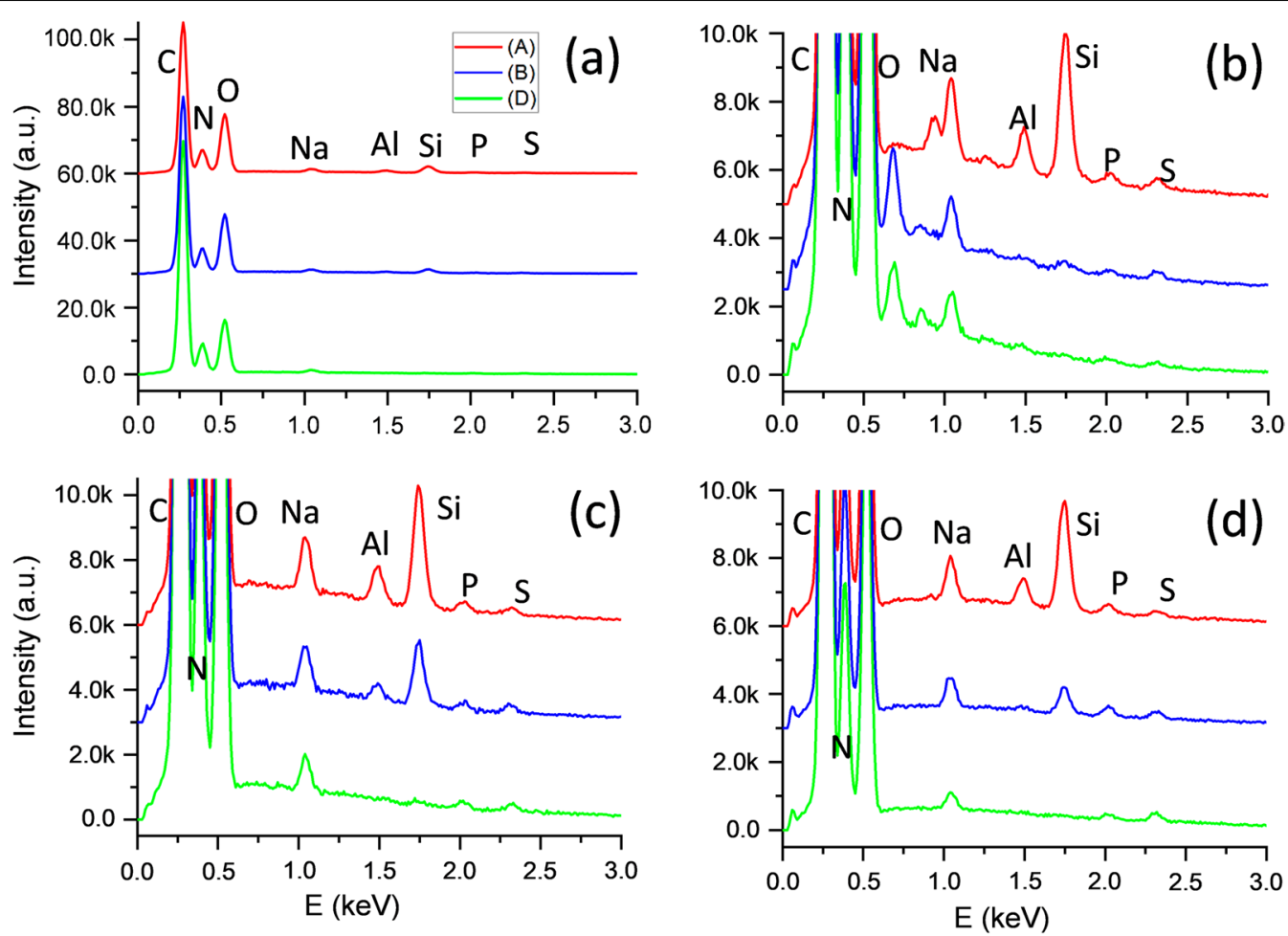

Fig. 3 EDX spectra normalized to the N peak for samples S2, S3 and S4, obtained from regions A (red), B (blue) and D (green) of a nodule for samples S3 (images (a) and (c)), S2 (b) and S4 (d)

Table 5 Radiological classification and progression and their correspondent averaged Si and Al EDX detected percentages

\begin{tabular}{|c|c|c|c|c|c|c|c|}
\hline Patients & $\begin{array}{l}\text { CRX ILO } \\
\text { classification* }\end{array}$ & $\begin{array}{l}\text { Main HRCT } \\
\text { findings** }\end{array}$ & $\begin{array}{l}\text { CRX ILO } \\
\text { classification }^{\dagger}\end{array}$ & $\begin{array}{l}\text { Main HRCT } \\
\text { findings }{ }^{\ddagger}\end{array}$ & $\underset{\xi}{\operatorname{Si}}(\%)$ & $\underset{\xi}{A I}(\%)$ & $\begin{array}{l}\text { Progression } \\
\text { rate per Year } \\
\text { (PRY) }\end{array}$ \\
\hline S1 & $\mathrm{SS} 2 / 3 \mathrm{q} / \mathrm{t}$ & $\mathrm{A}, \mathrm{B}, \mathrm{F}$ & FMP A & $\mathrm{A}, \mathrm{B}, \mathrm{E}, \mathrm{D}, \mathrm{F}$ & 0.07 & 0.0525 & 0.2727273 \\
\hline S2 & PMF B & $A, B, E$ & FMPC & $\mathrm{A}, \mathrm{B}, \mathrm{E}$ & 0.595 & 0.165 & 0.0909091 \\
\hline S3 & $\mathrm{SS} 2 / 2 \mathrm{r} / \mathrm{q}$ & $A, B, D$ & FMP B & $\mathrm{A}, \mathrm{B}, \mathrm{D}, \mathrm{E}$ & 1.1325 & 0.3075 & 0.4545455 \\
\hline S4 & $\mathrm{SS} 2 / 3 \mathrm{r} / \mathrm{q}$ & $A, B, C$ & FMPC & $A, B, D, E$ & 1.1025 & 0.3075 & 0.4545455 \\
\hline S5 & SS $3 / 2$ r/q & A & SS $3 / 3$ r/q & $A, B$ & 0.05 & 0.0875 & 0.0909091 \\
\hline S6 & SS $1 / 2$ q/q & $A, B, C$ & SS $1 / 2 \mathrm{q} / \mathrm{q}$ & $A, B$ & 0.085 & 0.1725 & 0 \\
\hline S7 & $\mathrm{SS} 2 / 2 \mathrm{q} / \mathrm{t}$ & $A, B$ & $\mathrm{SS} 2 / 2 \mathrm{q} / \mathrm{t}$ & $A, B$ & 0.2775 & 0.0675 & 0 \\
\hline
\end{tabular}

${ }^{*}$ At the time of lung biopsy. ${ }^{\dagger}$ Last follow-up visit. ${ }^{*}$ Last HRCT. ${ }^{\xi}$ Averaged percentages of the EDX measurements at 4 regions (A to D) of each sample, obtained from the data in Table 4

SS Simple Silicosis, PMF Progressive Massive Fibrosis, $A$ small nodular (round) opacities, $B$ hilar and mediastinal lymphadenopathy, $C$ ground-glass opacities, $D$ Calcified lymphadenopathy, $E$ Large opacities, $F$ Interlobular septal thickening

Linear relationship between progression rate per year (PRY) and Si was statistically significant $(r=0.78$, $p=0.03$, IC 95\% 0.07-0.97); therefore, the higher atomic content of $\mathrm{Si}$ in the nodule, the more probable progression of the illness. Linear relationship between $\mathrm{PRY}$ and $\mathrm{Al}$ was near significant $(\mathrm{r}=0.71, p=0.07, \mathrm{IC}$ $95 \%-0.09-0.95)$.
In simple linear regression models, Si coefficient was statistically significant $(p<0.05)$. The coefficient estimate was 0.33 , which means that an increase in one unit in the average atomic content of $\mathrm{Si}(\%)$ increases the annualized progression rate by 0.33 . However, it is not easy to discriminate the role of both in the progression 
of the disease because the correlation between $\mathrm{Si}$ and $\mathrm{Al}$ is very high $(\mathrm{r}=0.93)$.

\section{Discussion}

The Bay of Cadiz has suffered one of the largest known outbreaks of silicosis in ES workers. The first cases appeared in 2009, and although cases continue to appear today, the largest number of diagnoses occurred between 2010 and 2013 [11]. With this study, we aimed to elucidate if there may be factors other than silica, and inherent to the composition of countertops, that may be involved in the development of the disease.

The first objective of our study was to analyze the composition of the material with which our patients had been working in the years prior to diagnosis. As expected, the fundamental component found was silica, with percentages ranging from 87.2 to $99.5 \%$, a result that is in agreement with the data presented by most authors [3, 12-14]. Among the $\mathrm{SiO}_{2}$ polymorphs found, two samples were formed almost entirely of cristobalite (M1 and M3), while quartz was the only component in two of the samples (M6 and M7); in other samples, similar percentages of both components were found.

Historically, cristobalite has been considered more harmful than quartz, but more recent studies have shown that the pathogenic effects are similar; consequently, the Occupational Safety and Health Administration (OSHA) has concluded that quartz, cristobalite and tridymite have similar toxic and carcinogenic potential [15].

In relation to the presence of noxious metallic elements in the samples, the complex and heterogeneous composition is noteworthy. Pavan and colleagues [3] detected, in addition to $\mathrm{Si}$, up to 11 possible elements $(\mathrm{Na}, \mathrm{Mg}, \mathrm{Al}$, $\mathrm{S}, \mathrm{K}, \mathrm{Ca}, \mathrm{Ti}, \mathrm{Fe}, \mathrm{Co}, \mathrm{Cu}, \mathrm{Zn}$ ); $\mathrm{Al}$ was present in different amounts in five of the samples. Di Benedetto and colleagues [12], in their samples, detected between 13 and 17 metals, in addition to $\mathrm{Si}$, with a wide variability in the composition, with $\mathrm{Ca}$ and $\mathrm{Na}$ being the majority; others such as $\mathrm{Mg}, \mathrm{Al}, \mathrm{K}$ and $\mathrm{Ti}$ were frequently found in lower concentrations.

In this sense, samples M1 to M7 in our study showed to a greater or lesser extent the presence of 17 quantifiable metals. One of the elements systematically detected in all samples was tungsten. This has not been reported for any previous series, and we cannot rule out that the procedure used by us to obtain the dust samples could have led to $\mathrm{W}$ contamination (steel bits with tungsten carbide tips). The addition of elements contributing to ES dust has been verified by other authors who used similar tools in the processing of the material; the results can also differ based on dry or wet processing [12].

In our countertop samples, the metals found in the highest concentrations were $\mathrm{Na}, \mathrm{Ca}, \mathrm{Al}, \mathrm{Ti}$ and $\mathrm{Fe}$, accompanied by variable amounts of the other metals. Various types of metals have been implicated in the development of lung diseases of occupational origin. Chiba and colleagues described, on high resolution computerized tomography (HRCT), the presence of ground glass opacities, consolidations and centrilobular micronodules in a hard metal worker. Transbronchial biopsy exhibited chronic fibrotic and inflammatory changes, and the mineralogical analysis of lung tissue detected hard metals such as $\mathrm{W}, \mathrm{Ti}$ and $\mathrm{Fe}$, which were also detected in dust samples from the workplace [16]. Tomioka and colleagues described the existence of a micronodular pattern on HRCT and granulomatous lesions in the biopsy of a worker in an aluminum and battery processing factory [17]. In the analysis of the lung samples, the presence of silicon, iron, aluminum and titanium in the granulomas was confirmed. Aluminum, in particular, was distributed in a relatively high concentration in granulomatous lesions. Iijima and colleagues described ground glass opacities on HRCT, and on biopsy, bronchiocentric macrophage accumulation and peribronchiolar fibrosis were detected. The analysis found high amounts of aluminum and iron [18].

To our knowledge, the study presented herein is the first to analyze the distribution of $\mathrm{Si}$ and other metals in pulmonary nodules in ES silicosis. We obtained seven lung samples from the Anatomic Pathology files of two hospitals. In the analysis of our lung samples, we found that the pulmonary nodules have significant percentages of two fundamental exogenous elements, $\mathrm{Si}$ and $\mathrm{Al}$, and that their atomic content was higher in the most central area of the nodule and decreased progressively in the periphery. This result highlights the significant accumulation of $\mathrm{Al}$ in nodules and is also a relatively abundant metallic element found in samples M1-M7 of countertops with which our patients worked prior to disease diagnosis. The higher concentration of $\mathrm{Si}$ and $\mathrm{Al}$ particles in the center of the nodules suggests that the cellular reactions begin at this point, precisely where the levels of silica and $\mathrm{Al}$ are higher.

The role of aluminum in silicosis has been historically controversial; in fact, from 1943 to 1979 thousands of miners were forced to inhale McIntyre Powder (a mixture of aluminum and aluminum hydroxide) [19] during years, for about $10 \mathrm{~min}$ before the underground work shift, with the aim to prevent the development of silicosis. As result, aluminum content in exposed miners' lungs was three times higher than non-exposed [20]. The program ended in Canada in 1980 because it was concluded that this procedure granted no protective effect against silicosis [21].

Occupational exposure to $\mathrm{Al}$ has been associated with different histopathological patterns, including severe 
interstitial pulmonary fibrosis [22-24]. Assad and colleagues reported that aluminum inhalation can cause different phenotypes of interstitial lung disease, such as usual interstitial pneumonia or nodular pulmonary fibrosis [25]. It is possible that the differentiation of the interstitial lung disease phenotype in workers exposed to aluminum may depend on the type and intensity of exposure and the presence of concomitant exposures, such as silica, smoking and unknown host factors.

Abraham and Wiesenfeld described two cases of accelerated silicosis in sandblasting workers in which the mineralogical analysis of PMF lesions revealed not only silica but also aluminum silicate and other metals in significant amounts [26]. Halldin and colleagues studied the lung biopsy of a miner with category A PMF [27]. Of the 335 particles analyzed, $12.2 \%$ were silica, $82.4 \%$ were aluminum silicates, and $4 \%$ were titanium dioxide. The histopathological studies developed by Cohen and colleagues suggest that silica and silicates play an important role in the development of accelerated pneumoconiosis; however, in that study, no description was made of the metals that formed the silicates [28]. Jederlinic and colleagues described patients with pulmonary fibrosis, with more than $90 \%$ aluminum among the metals detected in the lung samples in workers exposed to alumina $\left(\mathrm{Al}_{2} \mathrm{O}_{3}\right)$ [29], and Kraus and colleagues found ill-defined centrilobular nodular opacities detected by HRCT in $24.2 \%$ of aluminum powders workers [30]. Finally, Taiwo concluded that some evidence suggests that exposure to aluminum dusts and fumes may cause diffuse parenchymal changes, granulomas, pulmonary alveolar proteinosis and desquamative interstitial pneumonia[31]. One of our countertops samples (M2) contained 2.5\% Aluminum (Al is contained in more complex albite compound), and $\mathrm{Di}$ Benedetto detected $\mathrm{Al}$ in all samples tested [12]. Aluminum, described as an elemental solid or as part of compounds or minerals, has been reported in other countertop samples [3, 13, 32].

Ophir and colleagues studied the composition of elements in the induced sputum of three workers exposed to processed ES and another three not exposed [33]. In both, different elements were found, but silicon, titanium, zinc and aluminum were only found in exposed patients. In this case, it was found that the $\mathrm{Al}$ concentration was similar to that of Si. The authors also studied samples of natural and artificial stone dust obtained from two industrial plants that worked exclusively on a single type of stone and found that the ES powder had 160 times more $\mathrm{Si}$ than that in powder obtained from a natural stone factory, and that the $\mathrm{Al}$ concentration was 22 times higher in ES powder than in natural stone. Studies on animals have shown that aluminum inhalation induces epithelial cell damage and an increase in collagen deposition and matrix metalloproteinases [34] and, on the other hand, it is known that aluminum salts, as aluminum hydroxide, increase the inflammatory response and induce the differentiation of monocytes into dendritic cells and macrophages. Aluminum particles are phagocyted by these cells (macrophages and dendritic cells), and they cause disruption of the phagolysosomes and release of active cathepsin B into the cytoplasm which may be a sufficient signal for NLPR3 (also named as NALP3) activation inflammasome, resulting in the release of active IL-1 $\beta$ and IL-18 [35, 36], and this is also a well-known pathogenic mechanism in silicosis $[37,38]$. Furthermore, Al can induce DNA damage by oxidative stress or liberation of DNase [39]. Finally, Mandler and colleagues have demonstrated in mice that oropharyngeal aspiration of dust from a solid-surface composite composed of alumina trihydrate and acrylic polymer induced, in bronchoalveolar lavage fluid, a significant inflammatory response (lactate dehydrogenase activity, inflammatory cells, and pro-inflammatory cytokines), in some cases to a greater degree than the silica positive control. Histologically they found acute alveolitis at day 1 after exposure and alveolar particle deposition and granulomatous mass formation at day 14 [40].

The high proportion of $\mathrm{Al}$ in all our samples, in some cases with an $\mathrm{Al} / \mathrm{Si}$ ratio higher than 1, raises the hypothesis that aluminum may play a role in ES silicosis, possibly enhancing the inflammatory response to silica or even causing an inflammatory reaction by itself.

Recently, Fireman and co-workers investigated silica and metals in lung tissues of patients that underwent lung transplantation due to ES silicosis and others due to Idiopathic Pulmonary Fibrosis. They found that only silica, titanium and aluminum were significantly higher

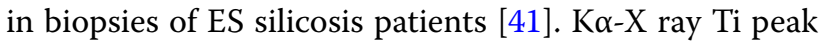
is centered at $4.5 \mathrm{keV}$, within the range of our spectra (up to $5 \mathrm{keV}$ ). Therefore, if there is any Ti within the biopsies in our study, either it was a percentage below the detection threshold in the silicotic nodules, or the amount of Ti-containing particles was so low it passed undetected during the SEM study. A number of other exogenous elements, environmental and genetic factors different to $\mathrm{Si}$ and $\mathrm{Al}$ are of importance for the development of silicosis.

Although some researchers have studied the mineralogical and metallic composition of countertops, their organic components have only been partially studied [3]. This organic content can represent up to $14.3 \mathrm{wt} . \%$ of ES [32].These compounds are part of the resins used in manufacturing and reach the lungs as part of the dust particles inhaled during the working processes (cutting, drilling, polishing, etc.). Recently, Halls and colleagues have detected measurable concentrations of a wide range of VOCs emitted when cutting ES [42]. Although we do 
not know the pathogenic role of these compounds in ES workers, it should be taken into account that subchronic exposure to low-dose VOCs (formaldehyde, benzene, toluene, and xylene) produces bronchial and lung inflammation in animal models [43] and some low molecular weight PAHs, such as phenanthrene and fluorene, induce oxidative stress and inflammation in human lung epithelial cells and the combined action of both is more potent than individually [44].

On the other hand, styrene has been associated with bronchial asthma [45, 46] eosinophilic bronchitis [47], hypersensitivity pneumonitis and organizing pneumonia [48] and toluene affects respiratory system [49]. Toluene was detected in four of our countertop samples, while styrene was found in all of them. This could explain, then, that the spectrum of diseases related to manufacturing or manipulation of ES is broader than silicosis. Therefore, it would be necessary to take into account that work-related respiratory symptoms could be caused also by organic compounds and could explain the high rate of respiratory symptoms in ES workers without silicosis, which in some series affect up to one third of them [50].

The main limitation of our study is that the association found here does not, in itself, infer causality. Also, it can be argued that the number of biopsy samples is not high enough to support some conclusions, and so, the association founded between $\mathrm{Al}$ and $\mathrm{Si}$ may be a coincidence. Nevertheless, the fact that in all the studied samples $\mathrm{Al}$ and $\mathrm{Si}$ containing particles are found in significant amount merits further investigation. To the date, once the ES high power to produce silicosis is confirmed, the diagnosis, mostly, is not obtained through biopsy, but via exposure antecedents and chest radiography (CXR) or High-resolution CT (HRCT), thus, it has to be noted that obtaining lung samples for diagnosis is currently only justified in the cases of atypical presentations.

Until recently, exposure to ES was basically limited to its manufacture in large factories or to the completion and finishing of the product into bathroom and kitchen countertops by small companies. In such work environment, the continuous inhalation of this material has caused a multitude of cases worldwide, described by some as an epidemic [9], of which we are probably only seeing the tip of the iceberg [51]. This suspicion is reinforced by some studies; screening in ES workers in California has shown that $12 \%$ suffer from silicosis, diagnosed by chest radiology and ILO classification [52]. In addition, a more exhaustive evaluation in workers in Victoria (Australia) using chest radiology and HRCT showed that the percentage of patients with silicosis increased to $36 \%$ because HRCT detected cases with negative chest radiology [53]. If we consider that the number of exposed workers in the US is close to 100,000 , we will have an idea of the magnitude of the problem. Therefore, it is necessary to find safer materials for workers, in addition to optimizing occupational prevention measures.

\section{Conclusions}

In conclusion, some of the VOCs and PAHs that we have found in our samples of countertops has been described as causative of respiratory disease and lung inflammation. Within the silicotic nodules, the detected aluminum content can be considered high, and it is, in some cases, higher than the silicon one. Both exogenous elements decrease their content from the center to the frontier of the nodule. In any case, further studies are needed to clarify any specific role of the aluminum regarding the ES silicosis. Experimental studies with cell cultures and animal models with various types of ES with different compositions can help to more accurately define the potential aggressiveness of the different elements and organic compounds of ES.

\section{Materials and methods}

The Spanish National Association of Silicosis-Affected and -Sick People (Asociación Nacional de Afectados y Enfermos de Silicosis-ANAES) was asked to send us samples of the countertops most frequently used by workers in our region in the years prior to the outbreak; we received seven representative samples of different models manufactured by two commercial companies.

The present study was performed on these seven solid samples (M1 to M7), and seven lung specimens of patients diagnosed previously with ES silicosis by lung biopsy (S1 to S7). Besides, one lung biopsy from an unexposed patient was used as a control sample.

\section{Preparation and analysis of the countertop samples:}

The mechanical disaggregation of each of the slabs (M1 to M7) was performed within an isolation hood in a laboratory area without environmental contaminants. The samples, in the form of fine powders, were generated from the friction of a 6 -mm Wolfpack ${ }^{\circledR}$ professional widia drill bit using a low drilling speed until a sufficient amount of sample (2 cubic centimeters) was obtained. Figure 4 shows representative images of the countertop samples, the drill bit used and the powder extracted.

These powdery samples were processed using various procedures, which are described below, to obtain the complete composition and structure information of the crystalline and amorphous portions of each of the samples.

\section{Identification of crystalline phases and major compounds}

Structural and compositional characterizations of each sample was performed through quantitative analysis 


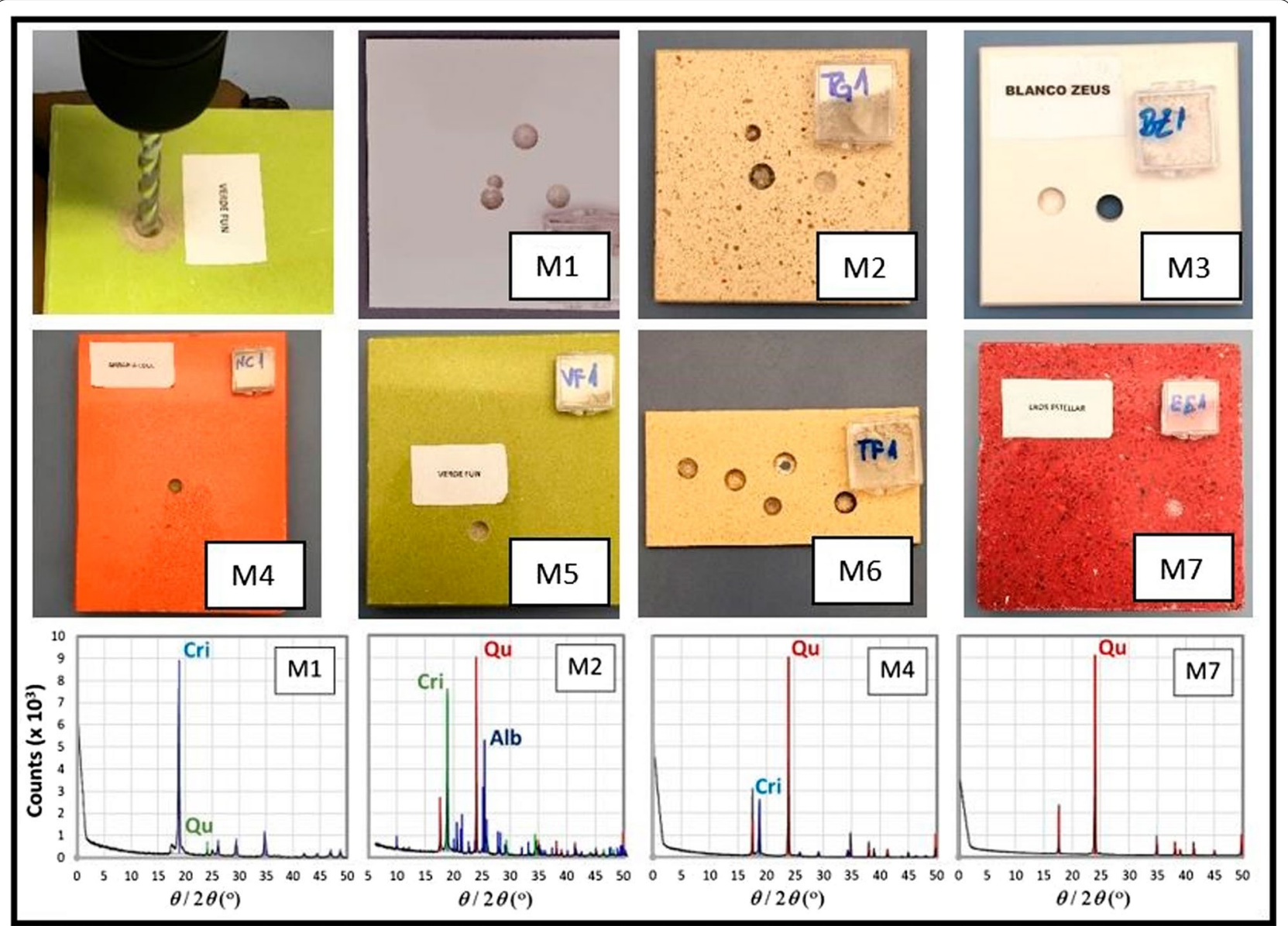

Fig. 4 Images of the countertops analyzed, the drill bit used, and the powder extracted and 4 XRD diagrams for 4 of the samples. Among them, the major crystalline phases of $\mathrm{SiO}_{2}$, i.e., quartz (Qu) and cristobalite (Cri), were detected, as well as minerals containing Na ( $\mathrm{AlSi}_{3} \mathrm{O}_{8}$ ), i.e., albite (Alb). In the sample $\mathrm{M} 4$, approximately $2 \%$ of crystals (other) comprised $0.7 \% \mathrm{SiO}_{2}$ tridymite, $0.4 \% \mathrm{TiO}_{2}$ rutile, $0.35 \% \mathrm{~Pb}_{4} \mathrm{BiVO}_{8}$, and $0.2 \%$ intermetallic $\mathrm{Sn}_{3} \mathrm{Ti}_{5}$

by X-ray diffraction (XRD) using the q-XRD Rietveld Refinement method and peak ratio analysis (RIR: reference intensity ratio), allowing the determination of the crystalline and amorphous components in multiphase mixtures. The identification of the most frequent elements was performed by X-ray fluorescence (XRF) using qualitative and quantitative standardless methods. The studies were carried out with the equipment and technicians at the X-ray Division of the Central Services of Science and Technology (Servicios Centrales de Ciencia y Tecnología-SC-ICYT) of the University of Cadiz (UCA): Bruker D8Advance A25 Davinci, with a LINXEYE detector, for XRD and Bruker M4 Tornado for XRF.

\section{Analysis of metals}

Seventeen metals were selected to be studied based on their harmfulness to humans or their possible presence in countertops. Detection was carried using the equipment and technicians of the Atomic Spectroscopy Division of
SC-ICYT at UCA. Thermo Elemental-X7 Quadrupole inductively coupled plasma mass spectrometer (ICP-MS) was used for detection of $\mathrm{As}, \mathrm{Cd}, \mathrm{Co}, \mathrm{Cu}, \mathrm{Ni}, \mathrm{Pb}, \mathrm{Zn}, \mathrm{Ba}$, $\mathrm{Mo}, \mathrm{Sb}, \mathrm{V}$, and $\mathrm{Al}, \mathrm{Fe}, \mathrm{Ca}, \mathrm{Na}, \mathrm{Ti}, \mathrm{W}$ were detected using an Iris Intrepid Thermo Elemental inductively coupled plasma atomic emission spectrometer (ICP-AES). To prepare the samples, $100 \mathrm{mg}$ of ES powder was digested with $5 \mathrm{~mL}$ of HF\% (pa), $3 \mathrm{~mL}$ of $65 \% \mathrm{HNO}$ and $1 \mathrm{~mL}$ of $30 \%$ $\mathrm{H}_{2} \mathrm{O}_{2}$ in an Ethos 1 microwave oven (Milestone, Italy) at $200{ }^{\circ} \mathrm{C}$ for $20 \mathrm{~min}$ to bring the sample to complete dissolution. The digestion products were filtered through a $0.45-\mu \mathrm{m}$ nylon filter, and the samples were flushed with ultrapure water (resistivity less than $18.2 \mathrm{M} \Omega \mathrm{cm}$ ) to a final volume of $50 \mathrm{~mL}$.

\section{Analysis of organic compounds}

To each of the dust samples obtained from the countertops, a precise volume of specific solvents (carbon disulfide, acetonitrile, hexane and methanol, 
high-performance liquid chromatography grade) was added to a mass determined from the powder sample to extract and measure the organic portions of the polymeric binder of the countertops (EPA method 3570). The suspension was incubated, and the extraction of the different compounds considered a priori (target compounds) was achieved by ultrasonic bath. This suspension was filtered through a controlled porosity filter $(0.2 \mu \mathrm{m})$ to remove solid particles. Then, the samples were processed for analysis by gas chromatography-mass spectrometry (GC-MS: Waters Synapt G2) coupled with a time-of-flight analyzer (high resolution) for the identification and quantification of volatile and semivolatile organic compounds (VOCs), polycyclic aromatic hydrocarbons (PAHs) and polychlorinated biphenyls (PCBs), aldehydes and ketones. For those compounds whose standards were available (PAHs, PCBs and some VOCs), identification and quantification were carried out with Masslynx software. The presence of characteristic masses (allowing an error of less than $5 \mathrm{ppm}$ ) and retention times were considered identification criteria to determine the concentrations in the different samples through corresponding calibration curves obtained for solvent-based standards [54]. The instrument provided linear responses in the range of concentrations up to $2000 \mathrm{ng} / \mathrm{g}$ ( $\mathrm{R} 2$ higher than 0.985), for those samples which presented higher levels a dilution factor was applied to the sample extract. The limits of detection (LOD, defined as the lowest concentration providing a signal to noise ratio of 3) and quantification (LOQ, defined as the lowest concentration providing a signal to noise ratio of 10) were calculated (Table 6). The intra-day repeatability in the peak areas for a calibration standard injected two consecutive days was lower than $16 \%$. For those compounds whose standard was not available (certain aldehydes, ketones, VOCs, etc.), the chromatographic peaks were compared with the mass spectra of the NIST (Standard Reference Database) library after analysis by GC-MS with electronic ionization (EI) and verification through the exact mass and elemental composition available in MassLynx software (unknown compounds or 'nontarget'). The analysis was performed at the mass spectrometry division of SCICYT at UCA.

\section{Patients and biopsy samples}

All patients had been diagnosed with ES silicosis previously at Puerta del Mar University Hospital and Puerto Real University Hospital (Cadiz, Spain) by lung biopsy. All the patients are currently followed up at our outpatient clinics. Electronic medical records, CXR, HRCT scans and histological samples were retrospectively reviewed. Chest radiographs were classified according to
Table 6 Analytical parameters (limits of detection, limits of quantification and regression coefficient) for the proposed method

\begin{tabular}{llllc}
\hline Compound & Type & $\mathbf{R}^{\mathbf{2}}$ & $\begin{array}{l}\text { LOD } \\
\text { (ng/g) }\end{array}$ & $\begin{array}{l}\text { LOQ } \\
\text { (ng/g) }\end{array}$ \\
\hline Acenaphtene & PAH & 0.993 & 0.97 & 3.22 \\
Acenaphtylene & PAH & 0.999 & 0.78 & 2.59 \\
Anthracene & PAH & 0.991 & 0.86 & 2.85 \\
Benz(a)anthracene & PAH & 0.985 & 0.48 & 1.62 \\
Benzo(a)pyrene & PAH & 0.985 & 1.93 & 6.44 \\
Benzo(b+k)fluoranthene & PAH & 0.987 & 1.39 & 4.63 \\
Benzo(ghi)perylene & PAH & 0.988 & 4.44 & 14.80 \\
Chrysene & PAH & 0.991 & 0.44 & 1.48 \\
Dibenz(ah)anthracene & PAH & 0.993 & 4.44 & 14.80 \\
Fluoranthene & PAH & 0.999 & 0.39 & 1.31 \\
Fluorene & PAH & 0.996 & 0.48 & 1.61 \\
Indene(123-cd)pyrene & PAH & 0.985 & 8.02 & 26.73 \\
Naphthalene & PAH & 0.996 & 2.48 & 8.25 \\
Phenanthrene & PAH & 0.997 & 0.91 & 3.04 \\
Pyrene & PAH & 0.998 & 0.37 & 1.22 \\
PCB101 & PCB & 0.993 & 0.47 & 1.58 \\
PCB138 & PCB & 0.989 & 0.98 & 3.28 \\
PCB153 & PCB & 0.995 & 1.23 & 4.11 \\
PCB180 & PCB & 0.990 & 1.65 & 5.51 \\
PCB28 & PCB & 0.989 & 0.95 & 3.16 \\
PCB52 & PCB & 0.990 & 0.36 & 1.20 \\
1Hexanol 2 ethyl & COV & 0.991 & 8.72 & 15.3 \\
Styrene & COV & 0.989 & 4.31 & 12.1 \\
Toluene & COV & 0.994 & 4.47 & 13.3 \\
Ethylbenzene & COV & 0.995 & 3.14 & 11.2 \\
124Trimethylbenzene & COV & 0.995 & 2.72 & 9.25 \\
1Methoxy 2 propanol & COV & 0.987 & 4.65 & 15.68 \\
n-butylacetate & COV & 0.989 & 6.27 & 21.29 \\
m-xylene & COV & 0.985 & 3.32 & 10.35 \\
p-xylene & COV & 0.986 & 3.32 & 10.35 \\
\hline & & & & \\
& & & \\
& & &
\end{tabular}

International Labour Office (ILO) criteria [55] by three trained readers.

\section{Preparation and study of histological samples}

All histological samples were obtained from paraffin blocks from the Anatomic Pathology files of Puerta del Mar University Hospital and Puerto Real University Hospital (Cadiz, Spain). Samples taken by VATS were between 4.5 and $7 \mathrm{~cm}$ in length. Biopsies taken by BTB were between 1 and $2 \mathrm{~mm}$ in length. The number of biopsies by BTB ranged between one and four per patient. We studied all lung biopsies of our two hospitals diagnosed with silicosis that had worked with ES. Five-micron sections were cut from the paraffin blocks, and after staining the sections with hematoxylin-eosin, Periodic Acid-Schiff 
(PAS), and Ziehl-Neelsen, biopsies were studied by light microscopy.

Next, samples underwent a preparation process, following a standard protocol for biological samples [56], in order to be studied under an electron beam (which implies to be deposited in a vacuum chamber). First, a deparaffinization step was needed to remove the biologic material from the paraffin blocks (since otherwise SEM signals would come only from paraffin layers). Except for samples S6 and S7 (which size can be observed in Fig. 1), all biopsy samples presented lengths between 1 and $2 \mathrm{~mm}$, and even lower depths. Therefore, from that point, a careful micromanipulation took place in order to avoid destroying or even bending or distorting the samples, since locating a microscopic area (nodule) in a millimetric-size sample using a SEM microscope might be highly time-consuming. Therefore, the micrographs obtained from light microscopy were utilized as road maps for locating the silicotic nodules in SEM microscopy, which imply avoid changing the shape of the sample from the way it was received in the paraffin block. Such ideas were taking into account throughout the following dehydration process (which removed the remaining paraffin in the samples using progressive concentrations of acetone) and during the final critical point process, which allow to refill the biological dehydrated tissue with $\mathrm{CO}_{2}$, so the SEM images correspond to a realistic image of this tissue before it was removed from the patient lung.

Once the samples were prepared, they were studied using a Zeiss-Auriga and a Nova-NanoSEM 450 (both with field effect guns as electron sources), working at $5 \mathrm{kV}$ in order to obtain EDX signal while avoiding contamination deposition on the studied area. The first microscope is located at the Centro de Investigación, Tecnología e Innovación (CITIUS) facilities (Seville, Spain), while the second microscope is located at the Servicios Centrales de Investigación, Ciencia y Tecnología (SC-ICYT) facilities (Puerto Real, Spain).

\section{Statistical analysis}

\section{Al and Si spatial concentrations}

Differences in atomic content of $\mathrm{Si}$ and $\mathrm{Al}$ between regions at the center of the nodule (A), close to the center (B), periphery $(C)$ and outside (D) the nodule were calculated with a Friedman test due to the common withinindividual association and the lack of normality and homoscedasticity within each group. Shapiro-Wilk and Fligner-Killeen tests were used to contrast normality and homoscedasticity. Durbin-Conover post-hoc tests with Holm correction on p-values were carried out to contrast pairwise difference among nodule regions. Spatial relationship of the different regions $\mathrm{A}$ to $\mathrm{D}$ was not taken into account.

\section{$\mathrm{Al}$ and $\mathrm{Si}$ in disease progression}

Statistical relationships between $\mathrm{Al}$ and $\mathrm{Si}$ atomic contents and the annual progression of silicosis were also studied.

As a mean to determine the relationships between $\mathrm{Si}$ and $\mathrm{Al}$ atomic contents and annualized illness progression, a linear assumption was made for ILO scale. This linearized scale considers every change in one ILO position as a one unit increase in severity. With this new variable, the progression rate per year (PRY) was defined as:

$$
P R Y=\frac{\Delta S}{t}\left(\text { year }^{-1}\right)
$$

where $\Delta S$ represents the number of positions in ILO scale that the patient has got worse over the follow-up time and $t$ represents the number of years of follow-up.

Concentrations of $\mathrm{Si}$ and $\mathrm{Al}$ were calculated as averaged percentages of the EDX measurements at four regions (A to D) for each sample. Linear correlations between these two variables were estimated by Pearson correlation coefficient $(r)$. Simple linear regressions were also performed with PRY as response variable and $\mathrm{Al}$ and Si concentrations as predictive variables. Normality of residuals was assessed using QQ-plots.

A value of $p<0.05$ was established to determine statistical significance. All the analyses were performed using $\mathrm{R}$ software ( $\mathrm{R}$ Core Team, 2021).

\section{Abbreviations}

AS: Artificial stone; BSE: Backscattered electron; EDX: Energy-dispersive X-ray spectroscopy; ES: Engineered stone; GC-MS: Gas chromatography coupled to mass spectrometry; HRCT: High Resolution Computerized Tomography; ICP-AES: Inductively coupled plasma atomic emission spectrometer; ICP-MS: Inductively coupled plasma mass spectrometry; LOD: Limit of detection; LOQ: Limit of quantification; PCB: Polychlorinated biphenyls; PAH: Polycyclic aromatic hydrocarbons; PMF: Progressive massive fibrosis; ROS: Reactive oxygen species; SEM: Scanning electron microscopy; VOC: Volatile and semivolatile organic compounds; XRD: X-ray diffraction; XRF: X-ray fluorescence.

\section{Acknowledgements}

The authors thank the (Spanish) National Association of Silicosis-Affected and -Sick People (Asociación Nacional de Afectados y Enfermos de SilicosisANAES) for their collaboration through their contribution of the countertop samples analyzed in this study. The Junta de Andalucía and FEDER cofounding through projects references AT-5983 Trewa 1157178, FEDER-UCA18-10788 (2020-2022) and salud-201800016448-tra also partly supported the present studies. The authors acknowledge the Centro de Investigación, Tecnología e Innovación (CITIUS) of the University of Seville and the Servicios Centrales de Investigación, Ciencia y Tecnología (SC-ICYT) of the University of Cádiz, for Scientific and Technical support.

\section{Authors' contributions}

Conceptualization: A L-J, M G-R, R G and FM M; Formal analysis: JM M, M G-R, MG P-H, JA L-L and P M-C; Funding acquisition: A H-M and A L-J; Investigation: JM M, M G-R, MG P-H, JA L-L, A H-M, N M-G, DD C-O and P M-C; Methodology: A L-J and FM M; Project administration: A L-J; Supervision: FM M: Validation: FM $M$; Writing — original draft: $A L-J, J M M$, and FM M; Writing_review \& editing: $A$ $L-J, J M M, M G-R, M G$ P-H, JA L-L, A H-M, R G, P M-C, N M-G, DD C-O and FM M. All authors read and approved the final manuscript. 


\section{Funding}

This research was funded by Association of Pneumology and Thoracic Surgery of the South, Spain, Grant 3/2018. The funders had no role in the design of the study; in the collection, analyses, or interpretation of data; in the writing of the manuscript, or in the decision to publish the results.

\section{Availability of data and materials}

All data and materials are included in the manuscript, tables and figures.

\section{Declarations}

\section{Ethics approval and consent to participate}

The study was conducted according to the guidelines of the Declaration of Helsinki and approved by the Research Ethics Committee of Cádiz (Spain) on November 29, 2018 (protocol No. 102/18). Written informed consent was acquired from all participants.

\section{Consent for publication}

Consent for publication is included in the written informed consent.

\section{Competing interests}

The authors declare that they have no competing interests.

\section{Author details}

${ }^{1}$ Pulmonology, Allergy and Thoracic Surgery Department, Puerta del Mar University Hospital, Cádiz, Spain. ${ }^{2}$ Biomedical Research and Innovation Institute of Cádiz (INiBICA), Cádiz, Spain. ${ }^{3}$ IMEYMAT: University Institute of Research in Electron Microscopy and Materials of the University of Cadiz, Puerto Real, Cádiz, Spain. ${ }^{4}$ Department of Condensed Matter Physics, School of Sciences, University of Cádiz, Puerto Real, Cádiz, Spain. ${ }^{5}$ Department of Anatomic Pathology, Puerta del Mar University Hospital, Cádiz, Spain. ${ }^{6}$ INMAR: University Research Institute of Marine Research, University of Cádiz, Puerto Real, Cádiz, Spain. ${ }^{7}$ Department of Physical Chemistry, CASEM, University of Cádiz, Puerto Real, Cádiz, Spain. ${ }^{8}$ Department of Analytical Chemistry, CASEM, University of Cádiz, Puerto Real, Cádiz, Spain. ${ }^{9}$ Department of Materials Science, Metallurgical Engineering and Inorganic Chemistry, School of Sciences, University of Cádiz, Puerto Real, Cádiz, Spain. ${ }^{10}$ Department of Anatomic Pathology, Puerto Real University Hospital, Cádiz, Spain. ${ }^{11}$ Department of Pulmonology, Puerto Real University Hospital, Cádiz, Spain.

Received: 4 April 2021 Accepted: 31 October 2021

Published online: 22 November 2021

\section{References}

1. Leung CC, Yu ITS, Chen W. Silicosis. Lancet. 2012;379:2008-18. https://doi. org/10.1016/S0140-6736(12)60235-9.

2. De Matteis S, Heederik D, Burdorf A, Colosio C, Cullinan P, Henneberger PK, Olsson A, Raynal A, Rooijackers J, Santonen T, Sastre J, Schlünssen V, van Tongeren M, Sigsgaard T. European Respiratory Society Environment and Health Committee. Current and new challenges in occupational lung diseases. Eur Respir Rev 2017;26:170080. https://doi.org/10.1183/16000 617.0080-2017.

3. Pavan C, Polimeni M, Tomatis M, Corazzari I, Turci F, Ghigo D, Fubini B. Editor's Highlight: Abrasion of artificial stones as a new cause of an ancient disease. Physicochemical features and cellular responses. Toxicol Sci. 2016;153:4-17. https://doi.org/10.1093/toxsci/kfw101.

4. Kramer MR, Blanc PD, Fireman E, Amital A, Guber A, Rhahman NA, Shitrit D. Artificial stone silicosis [corrected]: disease resurgence among artificial stone workers. Chest. 2012;142:419-24. https://doi.org/10.1378/chest. 11-1321.

5. Pérez-Alonso A, Córdoba-Doña JA, Millares-Lorenzo JL, Figueroa-Murillo E, García-Vadillo C, Romero-Morillo J. Outbreak of silicosis in Spanish quartz conglomerate workers. Int J Occup Environ Health. 2014;20:26-32. https://doi.org/10.1179/2049396713Y.0000000049.

6. Paolucci V, Romeo R, Sisinni AG, Bartoli D, Mazzei MA, Sartorelli P. Silicosis in workers exposed to artificial quartz conglomerates: does it differ from chronic simple silicosis? Arch Bronconeumol. 2015;51:e57-60. https://doi.org/10.1016/j.arbres.2014.12.010.
7. Rose C, Heinzerling A, Patel K, Sack C, Wolff J, Zell-Baran L, Weissman D, Hall E, Sooriash R, McCarthy RB, Bojes H, Korotzer B, Flattery J, Weinberg JL, Potocko J, Jones KD, Reeb-Whitaker CK, Reul NK, LaSee CR, Materna $\mathrm{BL}$, Raghu G, Harrison R. Severe silicosis in engineered stone fabrication workers - California, Colorado, Texas, and Washington, 2017-2019. MMWR Morb Mortal Wkly Rep. 2019;68:813-8. https://doi.org/10. 15585/mmwr.mm6838a1.

8. Hoy RF, Baird T, Hammerschlag G, Hart D, Johnson AR, King P, Putt $M$, Yates $\mathrm{DH}$. Artificial stone-associated silicosis: a rapidly emerging occupational lung disease. Occup Environ Med. 2018;75:3-5. https:// doi.org/10.1136/oemed-2017-104428.

9. Kirby T. Australia reports on audit of silicosis for stonecutters. Lancet. 2019;393:861. https://doi.org/10.1016/S0140-6736(19)30478-7.

10. Wu N, Xue C, Yu S, Ye Q. Artificial stone-associated silicosis in China: a prospective comparison with natural stone-associated silicosis. Respirology. 2020;25:518-24. https://doi.org/10.1111/resp.13744.

11. León-Jiménez A, Hidalgo-Molina A, Conde-Sánchez MÁ, Pérez-Alonso A, Morales-Morales JM, García-Gámez EM, Córdoba-Doña JA. Artificial stone silicosis: rapid progression following exposure cessation. Chest. 2020;158:1060-8. https://doi.org/10.1016/j.chest.2020.03.026.

12. Di Benedetto F, Giaccherini A, Montegrossi G, Pardi LA, Zoleo A, Capolupo F, Innocenti M, Lepore GO, d'Acapito F, Capacci F, Poli C, laia TE, Buccianti A, Romanelli M. Chemical variability of artificial stone powders in relation to their health effects. Sci Rep. 2019;9:6531. https:// doi.org/10.1038/s41598-019-42238-2.

13. Carrieri M, Guzzardo C, Farcas D, Cena LG. Characterization of silica exposure during manufacturing of artificial stone countertops. Int Environ Res Public Health. 2020;17:4489. https://doi.org/10.3390/ijerp h17124489.

14. Bartoli D, Banchi B, Di Benedetto F, Farina GA, laia TE, Poli C, Romanelli M, Scancarello G, Tarchi M. Silicosis in employees in the processing of kitchen, bar and shop countertops made from quartz resin composite. Provisional results of the environmental and health survey conducted within the territory of USL 11 of Empoli in Tuscany among employees in the processing of quartz resin composite materials and review of the literature. Ital J Occup Environ Hyg. 2012;3:138-43.

15. Occupational Safety and Health Administration. Occupational Exposure to Respirable Crystalline Silica; Final Rule. https://www.osha.gov/ laws-regs/federalregister/2016-03-25-1. Accessed 12 Oct 2020.

16. Chiba Y, Kido T, Tahara M, Oda K, Noguchi S, Kawanami T, Yokoyama M, Yatera K. Hard metal lung disease with favorable response to corticosteroid treatment: a case report and literature review. Tohoku J Exp Med. 2019;247:51-8. https://doi.org/10.1620/tjem.247.51.

17. Tomioka H, Kaneda T, Katsuyama E, Kitaichi M, Moriyama H, Suzuki E. Elemental analysis of occupational granulomatous lung disease by electron probe microanalyzer with wavelength dispersive spectrometer: two case reports. Respir Med Case Rep. 2016;18:66-72. https:// doi.org/10.1016/j.rmcr.2016.04.009.

18. Iijima Y, Bando M, Yamasawa H, Moriyama H, Takemura T, Niki T, Sugiyama Y. A case of mixed dust pneumoconiosis with desquamative interstitial pneumonia-like reaction in an aluminum welder. Respir Med Case Rep. 2017;20:150-3. https://doi.org/10.1016/j.rmcr.2017.02.002.

19. Zarnke A, Rasmussen PE, David MO, Eidi H, Kennedy K, Hedges K, Irick T, Thome C, Pirkkanen J, Boreham D. Physical and chemical characterization of mcintyre powder: an aluminum dust inhaled by miners to combat silicosis. J Occup Environ Hyg. 2019;16:745-56. https://doi.org/ 10.1080/15459624.2019.1657581.

20. Verma DK. Aluminum in the lungs of Ontario hardrock miners. Arch Environ Occup Health. 2020;75:75-8. https://doi.org/10.1080/19338 244.2019.1574703.

21. Investigation of Mclntyre powder exposure and neurological outcomes in the mining master file cohort: Final report. The Workplace Safety and Insurance Board of Ontario. Occupational Cancer Research Centre. Ontario Health (Cancer Care Ontario) Mar 2020. https://www. wsib.ca/en/mcintyre-powder-update. Accessed 5 Jan 2021.

22. Wyman AE, Hines SE. Update on metal-induced occupational lung disease. Curr Opin Allergy Clin Immunol. 2018;18:73-9. https://doi.org/ 10.1097/ACI.0000000000000420.

23. Raghu G, Collins BF, Xia D, Schmidt R, Abraham JL. Pulmonary fibrosis associated with aluminum trihydrate (Corian) dust. N Engl J Med. 2014;370:2154-6. https://doi.org/10.1056/NEJMc1404786. 
24. Carney J, McAdams P, McCluskey J, Roggli VL. Aluminum-induced pneumoconiosis confirmed by analytical scanning electron microscopy: a case report and review of the literature. Ultrastruct Pathol. 2016;40:155-8. https://doi.org/10.3109/01913123.2016.1141824

25. Assad N, Sood A, Campen MJ, Zychowski KE. Metal-induced pulmonary fibrosis. Curr Environ Health Rep. 2018;5:486-98. https://doi.org/10.1007/ s40572-018-0219-7.

26. Abraham JL, Wiesenfeld SL. Two cases of fatal PMF in an ongoing epidemic of accelerated silicosis in oilfield sandblasters: lung pathology and mineralogy. Ann occup Hyg. 1997;41(Suppl 1):440-7.

27. Halldin CN, Reed WR, Joy GJ, Colinet JF, Rider JP, Petsonk EL, Abraham JL, Wolfe AL, Storey E, Laney AS. Debilitating lung disease among surface coal miners with no underground mining tenure. J Occup Environ Med. 2015;57:62-7. https://doi.org/10.1097/JOM.0000000000000302.

28. Cohen RA, Petsonk EL, Rose C, Young B, Regier M, Najmuddin A, Abraham JL, Churg A, Green FHY. Lung pathology in U.S. coal workers with rapidly progressive pneumoconiosis implicates silica and silicates. Am J Respir Crit Care Med. 2016;193:673-80. https://doi.org/10.1164/rccm. 201505-10140C.

29. Jederlinic PJ, Abraham JL, Churg A, Himmelstein JS, Epler GR, Gaensler EA. Pulmonary fibrosis in aluminum oxide workers. Investigation of nine workers, with pathologic examination and microanalysis in three of them Am Rev Respir Dis. 1990;142:1179-84. https://doi.org/10.1164/ajrccm/ 142.5.1179.

30. Kraus T, Schaller KH, Angerer J, Hilgers RD, Letzel S. Aluminosis-detection of an almost forgotten disease with HRCT. J Occup Med Toxicol. 2006;1:4. https://doi.org/10.1186/1745-6673-1-4.

31. Taiwo OA. Diffuse parenchymal diseases associated with aluminum use and primary aluminum production. J Occup Environ Med. 2014;56(5 Suppl):S71-2. https://doi.org/10.1097/JOM.0000000000000054.

32. Maharjan P, Crea J, Tkaczuk M, Gaskin S, Pisaniello D. Metal ion release from engineered stone dust in artificial lysosomal fluid-variation with time and stone type. Int J Environ Res Public Health. 2021;18:6391. https://doi.org/10.3390/ijerph18126391.

33. Ophir N, Shai AB, Alkalay Y, Israeli S, Korenstein R, Kramer MR, Fireman E. Artificial stone dust-induced functional and inflammatory abnormalities in exposed workers monitored quantitatively by biometrics. ERJ Open Res. 2016;2:00086-2015. https://doi.org/10.1183/23120541.00086-2015.

34. Halatek T, Opalska B, Lao I, Stetkiewicz J, Rydzynski K. Pneumotoxicity of dust from aluminum foundry and pure alumina: a comparative study of morphology and biomarkers in rats. Int J Occup Med Environ Health. 2005;18:59-70.

35. Li H, Nookala S, Re F. Aluminum hydroxide adjuvants activate caspase-1 and induce IL-1 beta and IL-18 release. J Immunol. 2007;178:5271-6. https://doi.org/10.4049/jimmunol.178.8.5271.

36. Hogenesch H. Mechanism of immunopotentiation and safety of aluminum adjuvants. Front Immunol. 2013;3:406. https://doi.org/10.3389/ fimmu.2012.00406.

37. Hornung $V$, Bauernfeind F, Halle A, Samstad EO, Kono H, Rock KL, Fitzgerald KA, Latz E. Silica crystals and aluminum salts activate the NALP3 inflammasome through phagosomal destabilization. Nat Immunol. 2008;9:847-56. https://doi.org/10.1038/ni.1631.

38. Cassel SL, Eisenbarth SC, Iyer SS, Sadler JJ, Colegio OR, Tephly LA, Carter $A B$, Rothman PB, Flavell RA, Sutterwala FS. The Nalp3 inflammasome is essential for the development of silicosis. Proc Natl Acad Sci U S A. 2008;105:9035-40. https://doi.org/10.1073/pnas.0803933105.

39. Banasik A, Lankoff A, Piskulak A, Adamowska K, Lisowska H, Wojcik A. Aluminum-induced micronuclei and apoptosis in human peripheralblood lymphocytes treated during different phases of the cell cycle. Environ Toxicol. 2005;20:402-6. https://doi.org/10.1002/tox.20125.

40. Mandler WK, Qi C, Orandle MS, Sarkisian K, Mercer RR, Stefaniak AB, Knepp AK, Bowers LN, Battelli LA, Shaffer J, Friend SA, Qian Y, Sisler JD. Mouse pulmonary response to dust from sawing Corian $^{\circledR}$, a solid-surface composite material. J Toxicol Environ Health A. 2019;82:645-63. https:// doi.org/10.1080/15287394.2019.1640816.

41. Fireman E, Mahamed AE, Rosengarten D, Ophir NN, Kramer MR. Quantitation of silica contents in lung explants of transplanted patients: artificial stone-induced silicosis vs. idiopathic pulmonary fibrosis. Int J Environ Res Public Health. 2021;18:7237. https://doi.org/10.3390/ijerph18147237.

42. Hall S, Stacey P, Pengelly I, Stagg S, Saunders J, Hambling S. Characterizing and comparing emissions of dust, respirable crystalline silica, and volatile organic compounds from natural and artificial stones. Ann Work Expo Health. 2021. https://doi.org/10.1093/annweh/wxab055.

43. Wang F, Li C, Liu W, Jin Y, Guo L. Effects of subchronic exposure to lowdose volatile organic compounds on lung inflammation in mice. Environ Toxicol. 2014;29:1089-97. https://doi.org/10.1002/tox.21844.

44. Guo H, Zhang Z, Wang H, Ma H, Hu F, Zhang W, Liu Y, Huang Y, Zeng Y, $\mathrm{Li}$, Wang J. Oxidative stress and inflammatory effects in human lung epithelial A549 cells induced by phenanthrene, fluorene, and their binary mixture. Environ Toxicol. 2020. https://doi.org/10.1002/tox.23015.

45. Fernández-Nieto M, Quirce S, Fraj J, del Pozo V, Seoane C, Sastre B, Lahoz C, Sastre J. Airway inflammation in occupational asthma caused by styrene. J Allergy Clin Immunol. 2006;117:948-50. https://doi.org/10.1016/j. jaci.2005.12.1350

46. Nett RJ, Cox-Ganser JM, Hubbs AF, Ruder AM, Cummings KJ, Huang YT, Kreiss K. Non-malignant respiratory disease among workers in industries using styrene-A review of the evidence. Am J Ind Med. 2017;60:163-80. https://doi.org/10.1002/ajim.22655.

47. Arochena L, Fernández-Nieto M, Aguado E, del Potro GM, Sastre J. Eosinophilic bronchitis caused by styrene. J Investig Allergol Clin Immunol. 2014:24:68-9.

48. Meyer KC, Sharma B, Kaufmann B, Kupper A, Hodgson M. Lung disease associated with occupational styrene exposure. Am J Ind Med. 2018. https://doi.org/10.1002/ajim.22867.

49. Toluene - Health Hazards and Protective Measures |Occupational Safety and Health Administration. https://www.osha.gov/toluene/hazards-prote ctive-measures. Accessed 27 Dec 2020.

50. Guarnieri G, Salasnich M, Lucernoni P, Sbaraglia M, Putzu MG, Zuliani P, Rossi F, Vio S, Bianchi L, Martinelli A, Gottardo O, Bizzotto R, Maestrelli P, Mason $\mathrm{P}$, Carrieri M. Silicosis in finishing workers in quartz conglomerates processing. Med Lav. 2020;111:99-106. https://doi.org/10.23749/mdl. v111i2.9115.

51. Cohen RA, Go LHT. Artificial stone silicosis: removal from exposure is not enough. Chest. 2020;158:862-3. https://doi.org/10.1016/j.chest.2019.11. 029.

52. Heinzerling A, Cummings KJ, Flattery J, Weinberg JL, Materna B, Harrison R. Radiographic screening reveals high burden of silicosis among workers at an engineered stone countertop fabrication facility in California. Am J Respir Crit Care Med. 2021;203:764-6. https://doi.org/10.1164/rccm. 202008-3297LE.

53. Hoy RF, Glass DC, Dimitriadis C, Hansen J, Hore-Lacy F, Sim MR. Identification of early-stage silicosis through health screening of stone benchtop industry workers in Victoria, Australia. Occup Environ Med. 2021;78:296302. https://doi.org/10.1136/oemed-2020-106897.

54. Pintado-Herrera MG, González-Mazo E, Lara-Martín PA. Atmospheric pressure gas chromatography-time-of-flight-mass spectrometry (APGC-ToFMS) for the determination of regulated and emerging contaminants in aqueous samples after stir bar sorptive extraction (SBSE). Anal Chim Acta. 2014:851:1-13. https://doi.org/10.1016/j.aca.2014.05.030.

55. International Labour Office Guidelines for the Use of the ILO International Classification of Radiographs of Pneumoconioses. ILO Occupational Safety and Health Series No. 22 (Rev.2011). ISBN 978-92-2-125049-4. Revised edition, 2011. Geneva, Switzerland: International Labour Office; 2011.

56. Lowers HA, Breit GN, Strand M, Pillers RM, Meeker GP, Todorov TI, Plumlee GS, Wolf RE, Robinson M, Parr J, Miller R, Groshong S, Green F, Rose C. Method to characterize inorganic particulates in lung tissue biopsies using field emission scanning electron microscopy. Toxicol Mech Methods. 2018;28:475-87. https://doi.org/10.1080/15376516.2018.1449042.

\section{Publisher's Note}

Springer Nature remains neutral with regard to jurisdictional claims in published maps and institutional affiliations. 